\title{
DOES INSTITUTIONAL CHANGE REALLY MATTER? \\ INFLATION TARGETS, CENTRAL BANK REFORM AND INTEREST RATE POLICY IN THE OECD COUNTRIES
}

\author{
V. Anton Muscatelli* \\ University of Glasgow \\ Patrizio Tirelli \\ Universita' Statale Milano \\ Carmine Trecroci \\ University of Glasgow
}

\begin{abstract}
We estimate forward-looking interest-rate reaction functions for the $\mathrm{G} 3$ economies and for a group of countries which recently adopted inflation targets. Some significant shifts in the conduct of monetary policy are detected in the G3 countries, especially in the USA and Japan. In contrast with popular wisdom, it is only since the 1990s that policies in these countries begin to look consistent with an inflation-targeting regime. In addition, the introduction of inflation targeting and central bank reforms in countries like Sweden, Canada and New Zealand has not led to major changes in the way in which central banks react to the objectives of economic policy. In all cases changes in policy behaviour pre-date the introduction of inflation targets and central bank reforms. The paper challenges the one-size-fits-all attitude towards modern central bank policymaking which permeates a great deal of the current literature.
\end{abstract}

JEL Codes: E58, F41:

Keywords: monetary policy; inflation targets; central bank reform; reaction functions; interest rates

(*) Department of Economics, University of Glasgow, Adam Smith Building, Glasgow G12 8RT, United Kingdom. Fax: +44 141330 4940. E-mail: V.Muscatelli@udcf.gla.ac.uk

This is a revised and extended version of an earlier paper (Muscatelli and Tirelli, 1996). We are grateful to Bill Dewald, Charles Goodhart, Andy Haldane, Ulrich Woitek, Dan Thornton and participants at the Royal Economic Society 1999 Conference in Nottingham for helpful comments and suggestions on the earlier version of this paper. The usual disclaimer applies. 
The importance of institutions has become a central tenet of modern macroeconomics. The literature on time inconsistency in monetary policy sees the appointment of an independent central bank and inflation targeting as key elements in achieving price stability (Persson and Tabellini, 1997). Empirical studies have apparently confirmed this view, suggesting that in a large number of countries monetary policy is broadly consistent with an inflation targeting regime (see Clarida, Galì and Gertler, 1997). In this paper we report estimates of interest rate reaction functions for a number of OECD economies. We examine when significant changes in monetary policy behaviour have occurred in the G3 economies, where the institutional framework has remained remarkably stable, and in a number of other OECD countries where central bank reforms and inflation targets have been introduced (i.e. Canada, the UK, New Zealand and Sweden).

Whilst we confirm some earlier results (Clarida et al. 1998) on how central bank policies (and expectations) turned more conservative at the beginning of the eighties, we also detect some significant shifts in the subsequent conduct of monetary policy in the USA and Japan. In contrast with popular wisdom, it is only since the 1990s that policies in these countries begin to look consistent with an inflation targeting regime. In addition, the introduction of inflation targeting and central bank reforms in countries like Sweden, Canada and New Zealand has not led to major changes in the way in which central banks of those countries react to the objectives of economic policy. In all cases changes in policy behaviour pre-date the introduction of inflation targets and central bank reforms. Our results suggest that institutional change has ex-post confirmed the policy shift. In a way, these findings are consistent with the view that changes in society's attitude towards inflation - and the ensuing policies - are relatively more important than institutional arrangements (Posen 1993, 1995, McCallum, 1996).

The paper is structured as follows. In Section 1 we outline the main contributions and results of the paper. In Section 2, we provide a link between estimated interest rate reaction 
functions and the theory of monetary policy design. This provides the background for our empirical models. Our empirical estimates are presented in Section 3, and Section 4 concludes.

\section{Introduction: The Existing Literature and Key Results}

\subsection{Context: The Existing Literature}

There are several recent contributions on modelling interest rate reaction functions and we need to distinguish our contribution carefully from those of previous authors. In general three broadly different approaches have been used in modelling monetary policy behaviour. First, a number of researchers have used Vector Autoregressions (VARs) to estimate the way in which policy actions depend on a set of macroeconomic indicators, and how in turn policy actions are transmitted to key macro variables. Bernanke and Blinder (1992) use the US Federal Funds Rate to analyse the transmission mechanism in the US. Christiano et al. (1994), Bernanke and Mihov (1995, 1997) (inter alia) ${ }^{1}$ have refined this approach by analysing alternative measures of monetary policy and identification mechanisms for the estimated VARs. Second, some researchers have focused on estimating single-equation (structural) reaction functions for monetary policy instruments (see for instance, McNees, 1992, Groeneveld et al., 1996, Muscatelli and Tirelli, 1996, Clarida and Gertler, 1997, and Clarida et al., 1998). Third, Rudebusch $(1995,1996)$ uses data from forward-looking financial markets to construct measures of unanticipated shocks to monetary policy.

In this paper we adopt the second of these approaches. The third approach, which uses financial market data, is less useful in detecting major changes in the monetary authorities' policy behaviour and the implications of any changes for the stance of monetary policy. The VAR approach has some advantages in that it allows one to jointly model both the endogenous policy response and the impact it has on key macroeconomic indicators by making only minimal

\footnotetext{
${ }^{1}$ For an excellent survey, see Christiano et al. (1998) who analyse the advantages and pitfalls of the VAR approach to identifying monetary shocks.
} 
assumptions about the transmission mechanism and the timing in the authorities' reactions to new macroeconomic data. However, the results from VAR models do seem to depend critically on the assumptions made about which variables to include in the VAR, and on the existence of a timeinvariant transmission mechanism and reaction function (see Rudebusch, 1996). Given the number of variables one usually includes in a VAR and the limited number of observations, it becomes difficult to conduct any stability analysis by, say, using 'rolling VARs'. This is especially the case if there have been frequent changes in either the policy regime or in the financial system which might affect the timing of the policy response and the nature of the transmission mechanism ${ }^{2}$.

Indeed, as noted by Christiano et al. (1998), VAR modellers usually prefer not to report or to interpret estimated policy rules, because if the actual policy rule is forward-looking, the estimated coefficients of such VAR-estimated 'policy rules' will be difficult to interpret. Instead, VAR models are primarily designed to construct measures of monetary policy shocks for use in analysing the transmission of monetary shocks ${ }^{3}$. (Even though there are differing views of the robustness and usefulness of the monetary policy shock measures obtained from VARs - see Rudebusch, 1996, Bagliano and Favero, 1998, Christiano et al., 1998). Overall, it does seem that VARs are less useful in undertaking an empirical analysis of regime changes in the conduct of monetary policy.

\subsection{Key Results and Value Added}

Our focus on single-equation (forward-looking) structural reaction functions is similar to that in Clarida and Gertler (1997) and Clarida et al. (1998), and allows us to analyse shifts in monetary policy regimes using recursive estimation techniques. However, we extend these earlier studies in the following ways. First, by presenting recursive estimates of these reaction functions,

\footnotetext{
${ }^{2}$ Although Bernanke and Mihov (1995) do allow for a limited amount of time variation in their VAR model.

${ }^{3}$ See e.g. Eichenbaum and Evans (1995).
} 
we can detect marked changes over the last two decades in the way monetary policy has been conducted. Whilst confirming some of the earlier results in Clarida et al. (1998) that the beginning of the 1980s marks a watershed in the commitment to low inflation in some countries, we also find some new and surprising results. For instance, the announcement of explicit inflation targets and the move to more independent central banks in several OECD economies does not seem to have led to a major change in the way monetary policy reacts ${ }^{4}$ to the final objectives of economic policy in the 1990s. The change in policy behaviour pre-dates the introduction of inflation targets and central bank reforms. This has important implications for the large theoretical literature which has emerged on central bank independence. Furthermore, despite the move towards more flexible exchange rate arrangements in Europe, in a number of countries (including the UK and Sweden) external objectives continued to play an important part in interest-rate determination, much as they had in the 1980s.

Second, unlike Clarida et al., we use alternative methods to estimate our measures of expected inflation and potential output. This is based on the assumption that the private sector is imperfectly informed about the central bank preferences, whereas the central bank is imperfectly informed about the permanent and cyclical components of output growth. Interestingly this also leads to new results. Whilst the interest rate reaction functions for Germany is reasonably stable, there seem to be some signs that monetary policy rules in the US and Japan are less stable than one might have imagined over the period 1985-97. Our estimates suggest that US policy has shifted to react to inflationary expectations more vigorously, and with a shorter lead. This fits well with most anecdotal accounts of US policy in the 1990s, but is in sharp contrast with the

\footnotetext{
${ }^{4}$ These results are consistent with those obtained in related work by Groeneveld et al. (1996), who reject the hypothesis of a structural break following the switch to inflation targeting in Canada, New Zealand and the United Kingdom. However, their models are backward-looking, use mainly domestic target variables, and focus solely on the overall stability of the fitted reaction functions during the early 1990s. Our modelling approach in this paper examines the stability of the model parameters over a longer sample and uses a measure of expected inflation and of potential output. There are also alternative approaches in the literature to assess the impact of inflation targets. For instance, Freeman and Willis (1995), and King (1995) examine credibility effects on the yield curve, and Almeida and Goodhart (1996) use a variety of different methods to assess the impact of inflation targeting on the behaviour of monetary authorities.
} 
results of previous empirical studies. Moreover, we find that the output coefficient has the wrong sign in the mid-1980s, suggesting that real interest rates were too low at a time when the output gap was positive. Only in the 1990s does the output coefficient sign become positive once more. Our results stand in sharp contrast with those of Favero and Rovelli (1999), who argue that since 1982 the Fed acted as a strict inflation targeter, rejecting the hypothesis that output stabilisation is an independent argument in the loss function of the Fed ${ }^{5}$. Japanese policy also seems to have exacerbated the cycle in the late 1980s, and only seems to have attempted to stabilise the output gap post-1990. This confirms the suspicion that Japanese policy was inappropriately geared to external objectives (the relationship with the US) in the 1980s.

Third, our study provides some empirical evidence on the lead with which the expected inflation rate enters estimated reaction functions. This is of considerable interest to theoretical analyses of the trade-off between output and inflation variability in monetary policy design (see Haldane and Batini, 1998, Goodhart, 1999). There is no other empirical study that we are aware of which compares the forward-lookingness of monetary policy across OECD countries.

\section{Interest Rate Reaction Functions and the Theory of Monetary Policy Design}

In this section we show how a forward-looking interest rate reaction function can emerge from a simple Barro-Gordon-type theoretical model of monetary policy design. Consider the following model for current inflation in the presence of costly price-adjustment as in Calvo, (1983) or Rotemberg (1983) (Rotemberg and Woodford, 1998, propose a sticky-price model which has similar implications):

$$
\pi_{t}=p_{t}-p_{t-1}=\beta \pi_{t+1}^{e}+\varphi\left(y_{t}-y^{*}\right)
$$

\footnotetext{
${ }^{5}$ They estimate a model of the US economy which consists of a VAR specification for the output gap, inflation and a commodity price index over the period 1960-1998. By doing this they estimate the parameters in the aggregate demand and supply functions. Then they use GMM methods to estimate, over the period 1983-1998, an interest rate rule which allows to identify the Central bank desired trade-off between output and inflation. Their approach requires full information, rational expectations and invariance of the structural model to changes of the monetary policy regime.
} 
where current inflation, $\pi$ depends on inflation expectations and the current output gap, where $y^{*}$ is potential output. The output gap is given by:

$y_{t}-y^{*}=-s\left[R_{t}-R_{t}^{e}\right]+\varepsilon_{t}$

Output deviations from the natural rate depend on a supply shock, $\varepsilon_{t}$, and the deviations of the nominal interest rate $R_{t}$ (which is the policy instrument), from its expected value, $R_{t}^{e}$.

$R_{t}^{e}=r^{*}+\pi_{t+1}^{e}$

where $r^{*}$ is the (ex ante) real interest rate.

Following Svensson (1998), suppose that the monetary policy-maker's loss function is given by:

$$
L=\chi \boldsymbol{\Theta}_{t}-\pi * \mathbf{9}-\tilde{y} \mathbf{9}+\rho\left[R_{t}-E \mathbf{B}_{t} \boldsymbol{\Psi}+\rho_{1}\left(R_{t}-R_{t-1}\right)^{2}\right.
$$

where the authorities penalise not only deviations of output from an output target, $\tilde{y}$, which exceeds the natural level $y^{*}$ (as in Barro and Gordon, 1983), and of inflation from a target $\pi *$ (as in Svensson, 1997a), but also penalise deviations and changes in the policy instrument.

This formulation assumes that stabilisation policy via interest rate changes is costly, and that for this reason shocks are never fully stabilised in the long run. Svensson's (1997a) model highlights the risk of instability of an anti-inflationary policy by assuming that the policymaker penalises deviations of $R_{t}$ from zero. Instead the formulation in (4) assumes that the policymaker knows the level of inflationary expectations, and consequently chooses a sequence for $R_{t}$. However, in the event of shocks hitting the economy, the authority decides whether to deviate from the nominal interest rate implied by the state of inflationary expectations. Solving the model under discretion, so that the monetary authority minimises (4) with respect to the nominal interest rate, taking expectations as given, yields an interest rate reaction function:

$$
R_{t}=w r^{*}-A^{*}+b^{*} \pi_{t+1}^{e}+c^{*} \varepsilon_{t}+d^{*} R_{t-1}
$$

where the coefficients are: 


$$
\begin{aligned}
& w=\frac{s^{2} \varphi^{2} \chi+s^{2}}{\left[s^{2} \varphi^{2} \chi+s^{2}+\rho_{1}\right]} ; b^{*}=\frac{s^{2} \varphi^{2} \chi+s^{2}+\chi \beta \varphi s}{\left[s^{2} \varphi^{2} \chi+s^{2}+\rho_{1}\right]} ; \\
& c^{*}=\frac{s \varphi^{2} \chi+s}{\left[s^{2} \varphi^{2} \chi+s^{2}+\rho+\rho_{1}\right]} ; d^{*}=\frac{\rho_{1}}{\left[s^{2} \varphi^{2} \chi+s^{2}+\rho_{1}\right]} \\
& A^{*}=\frac{s \text { బิ }-y * \mathbf{Q} \chi \varphi s \pi *}{\left[s^{2} \varphi^{2} \chi+s^{2}+\rho_{1}\right]}
\end{aligned}
$$

Note that we need the interest rate adjustment costs $\rho_{1}$ to be not too large to avoid an unstable system following output shocks, as current inflation depends on expected future inflation $^{6}$. It is also important to note that, if one were to estimate a reaction function such as (5), the interpretation of the constant would be different from that in Clarida et al. (1998). Basically, our model implies that the constant $\left(w r^{*}-A^{*}\right)$ is a function of the real interest rate, inflation target and inflationary bias, while in Clarida et al. it is referred to as simply the long-run component of the real interest rate. This demonstrates that one has to be careful in interpreting the estimated parameters of an interest rate reaction function, as these largely depend on the assumptions one makes about the monetary authorities' loss function.

If there is no uncertainty about the monetary authorities' policy objectives ${ }^{7}$, both inflation and interest rates will fluctuate stochastically around a given mean ${ }^{8}$. However, in practice, the authorities policy goals may not be observable (see Faust and Svensson, 1998, Muscatelli 1998a,b), and may vary over time (see Cukierman, 1992). Suppose for instance that price and wage-setters are uncertain about the policy-maker's preferences over inflation (his/her credibility):

$$
\chi_{t}=\chi_{t-1}+\omega_{t} \quad \omega_{t} \sim\left(0, \sigma_{\omega}^{2}\right)
$$

\footnotetext{
${ }^{6}$ In general the system will be stable as long as $\chi \beta \varphi s>\rho_{1}$, which implies $b^{*}>1$, and that the expected inflation response to the output gap is positive. Under RE the reaction function in (5) yields the following equilibrium inflation rate:

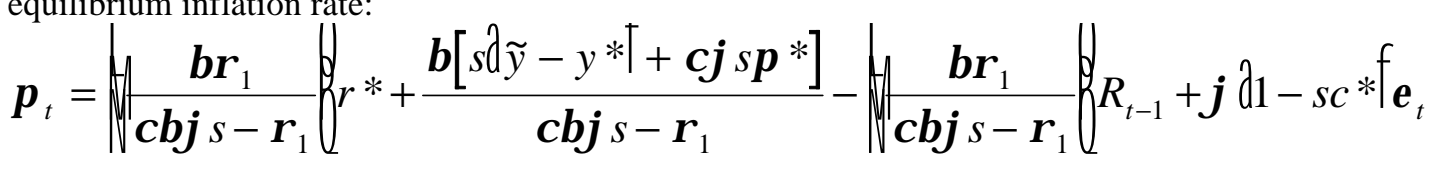

${ }^{7}$ Muscatelli (1998a,b) analyses a model of inflation targeting with uncertain central bank preferences.

${ }^{8}$ Given the nature of the supply shocks in the model, both inflation and interest rates will be stationary.
} 
Suppose also that the policy-maker cannot accurately predict the supply shock, but has to forecast it (this forecast being private information), and that wage and price-setters cannot disentangle the uncertainty due to the supply shock, $\varepsilon$, and the preference shock ${ }^{9}, \omega$. The private sector will then perceive the interest rate reaction function as:

$$
R_{t}=r *-\alpha_{0}+\alpha_{1} \pi_{t+1}^{e}+\alpha_{2} * \varepsilon_{t}^{f}+\alpha_{3} R_{t-1}
$$

where the $\alpha^{\prime}$ s are functions of the same parameters (and $\alpha_{1}>1$ like $b^{*}$ ) as in (7), but with $\chi^{e}$ (the expected value of $\chi$ ) and where $\varepsilon^{f}$ is the forecast of the supply shock. The private sector will update their expectations of $\chi$ and $\varepsilon^{f}$ each period on the basis of the variances of $\varepsilon$ and $\omega$ in a standard signal extraction problem (see Cukierman, 1992, Muscatelli 1998b, Walsh, 1998).

Thus, following a regime change (e.g. the central bank being granted independence), where some parameter of the monetary authority's objective function shifts, if the regime change was not fully credible one would see a gradual adjustment of inflation and interest rates to a new average level.

In practice one can estimate a forward-looking reaction function for interest rates along the lines of (7) by constructing a series for expected inflation and the expected supply shock (or equivalently the expected output gap), using an optimal updating scheme for the expected variables (such as the Kalman filter). If one then observes the timing of significant shifts in the estimated reaction function parameters these should correspond to major shifts in the policymaker's preferences (institutional regime) ${ }^{10}$.

It is worth noting that by estimating a simple forward-looking interest rate reaction function such as (7), one is not trying to capture the exact way in which the monetary authorities actually react to economic indicators which affect real economic activity and expected inflation. Instead estimated forward-looking reaction functions based on (7) capture the implicit way in

\footnotetext{
${ }^{9}$ In a monetary policy committee, the preference shock, $\omega$ can capture fluctuations in votes between different 'wings' of the committee.
} 
which CB's operational rules/decisions translate into a reaction function in terms of expected inflation and output gaps. Thus, for example, one might find some instability in the estimated reaction function parameters which may not be due to a change in policy preferences (price stability), but which might be due to a shift in the intermediate targets used to achieve this outcome $^{11}$. For instance in the case of the UK, we know that in the early 1980 s there was a move away from monetary targets once it became clear that monetary policy was becoming overcontractionary. But in general major and permanent shifts in estimated parameters will reflect corresponding shifts in policy preferences.

Therefore, estimating reaction functions such as (9) does not allow one to directly analyse the authorities' reactions to a full set of policy indicators, but it does allow one to judge whether the operational rules have been stable and whether the reliance on certain intermediate targets has been at the expense of meeting final output stabilisation and inflation objectives.

The theoretical literature on policy design has closely examined the performance of forward-looking (inflation expectations) policy rules (see Haldane and Batini, 1998, Faust and Svensson, 1998, Svensson, 1998). In part this is because of the emphasis given in some countries to the central bank's inflation forecast (cf. The Bank of England's regular inflation forecast based on current interest rate policies). In part it is because recent contributions to the inflation targeting debate (Svensson,1997b; Rudebusch and Svensson, 1998; Haldane and Batini, 1998) have shown the quasi-optimality of interest rate policy rules based on inflation forecasts. In general the form of the inflation forecast-based rules considered by these authors is:

$$
r_{t}=\theta r_{t} * \varphi r_{t-k}+\gamma E_{t} \pi_{t+j}+\lambda Q-y_{t} * \text { ? }
$$

\footnotetext{
${ }^{10}$ They might also be due to shifts in the underlying structural model which changes the way in which the authorities form their expectations about inflation and the output gap, but in this case we should observe changes in the models for expected inflation and the output gap.

${ }^{11}$ This point is also stressed by Christiano et al. (1998) in the context of VAR models.
} 
where $r_{t}$ is the short-term ex ante real interest rate, $r_{t}^{*}$ represents the long-run equilibrium real interest rate, while $E_{t} \pi_{t+j}$ is the $j$-period ahead inflation rate expected at $t$. Past values of the interest rate to capture interest-rate smoothing behaviour and the output gap are also included ${ }^{12}$. This can be re-written in terms of the nominal interest rate:

$$
R_{t}=\alpha+\varphi R_{t-k}+\omega E_{t} \pi_{t+j}+\lambda Q-y_{t} * \text { ? }
$$

where $\omega=(1+\gamma)$, while $\alpha$ includes the long-run real interest rate and the persistence in the forecast of inflation.

Comparing (9) with (7) we see that, by generalising the latter to include a longer lead for inflation, a longer lag for the interest-rate smoothing term, and substituting the output gap for the supply-shock forecast, (7) is identical to the forecast-based policy rule in (9).

In what follows, we estimate interest-rate reaction functions of the following type:

$$
\left.R_{t}=\alpha+\sum_{i=1}^{k} \varphi_{i} R_{t-i}+\omega E_{t} \pi_{t+j}+\lambda\right)-y_{t} * \mathbf{Q}
$$

Typically we find that a maximum lag length of $k=2$ is sufficient to capture the degree of interestrate smoothing. Having estimated the basic reaction function in (10), we then search for the appropriate lead $(j)$ for the inflation forecast term $E_{t} \pi_{t+j}$ on the basis of goodness-of-fit.

As noted in Haldane and Batini (1998), the specification of reaction functions such as (10) allows one to analyse a number of issues. First, the parameters $(\omega, j)$, i.e. the weight the bank puts on expected inflation and the lead term on it, determines the responsiveness of the instrument to changes in the forecast and the forward-lookingness of bank's horizon. In addition, the parameters $(j, k, \varphi)$ capture the degree of inertia in the interest rate policy. Finally, a value of $\lambda$ different from zero implies that the rule explicitly includes some reaction to deviations of output from potential.

\footnotetext{
${ }^{12}$ Batini and Haldane (1998) note that the omission of an output gap term does not mean that the authorities do not stabilise output, since by adjusting the degree of interest-rate smoothing and the lead in the inflation forecast one can trade off output stabilisation against inflation stabilisation.
} 
One potential problem in estimating structural reaction functions is highlighted by Favero and Rovelli (1999), who argue that finding a significant output effect in the reaction function might simply mean that the central bank treats the current output gap as a leading indicator for expected inflation. In this case the output gap should be collinear with the proxy for expected inflation, or should predict inflation forecast errors. We were not able, as explained below, to find substantial collinearity between our measures of inflation and the output gap, while the correlation with inflation forecast errors is very limited and often has the wrong sign ${ }^{13}$. Also, it is important to note that a leading indicator role for inflation is prevalently attributed, by both central bankers (Issing, 1997) and influential empirical contributions (Gerlach and Svensson, 1999), to some measure of tension in the money market, rather than to the output gap. We were however unable to detect such a role, as we shall see below.

\section{Empirical Estimates}

\subsection{The Monetary Policy Instrument Variables}

As in other recent attempts to estimate monetary authorities' reaction functions (see Clarida et al., 1998), we focus on short-term money market rates as the policy instrument ${ }^{14}$. Clearly there are difficulties in identifying a single interest rate measure as the monetary policy instrument for the whole of our sample period (see Bernanke and Mihov, 1995). One might want to use different interest rate measures as the policy instrument at different times (e.g. discount rates in the early part of the sample and repo or call money rates towards the end of the sample period). But such fine distinctions would inevitably be arbitrary, and in any case short-term money market rates will largely reflect the authorities' monetary policy stance under different operating procedures.

\footnotetext{
${ }^{13}$ These results are not shown here for reasons of brevity, but are available from the authors upon request.

${ }^{14}$ See the Data Appendix for details of the interest rate variables used.
} 


\subsection{Measuring Inflation Expectations and the Output Gap}

There are different methods to obtain measures of inflation expectations and the output gap. Clarida et al. (1998) use a Hodrick-Prescott-type non-linear trend to obtain a measure of potential output and hence deviations of actual output from this trend. In order to obtain a measure of inflation expectations, Clarida et al. (1998) use the errors-in-variables approach to modelling rational expectations whereby future actual values are used as regressors instead of the expected values, and instrumental variable estimation is used to take account of the presence of forecast errors.

Turning first to the output gap, one disadvantage of the Hodrick-Prescott procedure is that it involves using the full sample in the construction of the output trend, and hence using this filter implicitly involves making the assumption that the policymaker has future information on the path of output in the evaluation of the potential output trend. Rational expectations models which use the full sample similarly do not make allowances for gradual learning by the economic agent, as might be plausible in a situation where the monetary regime is not always constant over the sample period (see Cuthbertson et al., 1992).

Instead we use the Structural Time Series (STS) approach proposed by Harvey (1989) to generate series for the output gap and expected inflation. There are several advantages in using this approach. The first is that it provides a useful and intuitive way of decomposing a series into trend and cyclical components, which is particularly useful when one tries to estimate a series for an unobservable trend such as potential output. Second, the modelling approach lends itself readily to using a Kalman Filter estimation procedure, which allows one to proxy the learning process by policymakers and economic agents. Third, the structural time series models are parsimonious models which have reasonably rich ARIMA processes as their reduced forms. 
Essentially, we estimate models for real GDP and inflation for each country, seeking to disentangle the trend, cycle and irregular components ${ }^{15}$. In the case of GDP, a convenient decomposition of the series was made possible by applying the Kalman filter on the trend component. Subsequently, the latter was computed on the basis of one-step-ahead predictions of the state vector. This way, estimates of potential output are based only on past information, rather than on the full sample.

In the case of inflation, we simply computed one-step-ahead prediction errors from a univariate STS model to obtain a measure of expected and unanticipated inflation. Again, the models' parameters are updated only gradually, as new data is added. In both cases, the STS methodology makes the assumption that agents make the best use of all available knowledge in a regime of imperfect information. In contrast using a non-recursive estimation approach, such as IV errors-in-variables, has the defect of using information from the whole sample, thus ignoring policy regime shifts.

Our estimated potential output trends and expected inflation correspond well with descriptive accounts of macroeconomic conditions in the countries under consideration, and are illustrated in Appendix A (Figures A1.-A.3). Note that the output cycle looks less smooth than that obtained using smoothing filters such as the HP filter, because it includes a stochastic cycle. This is appropriate in this context as in practice the policymaker finds it difficult to disentangle the cyclical and irregular components in the output cycle. The greater the uncertainty about the stochastic process driving output the more our cycle measures look "irregular" relative to measures of the cycle obtained using detrending filters based on full sample information.

\subsection{Estimating Policy Rules}

In estimating (12) the appropriate reaction lead to expected inflation $(j)$ was usually found to be 4 quarters for most countries. This result broadly agrees with the findings of Batini

\footnotetext{
${ }^{15}$ The STAMP 5.0 software was used to estimate the STS models. Output and inflation were found to be I(1), and to have a significant cyclical component. The estimates STS models are available on request from the authors.
} 
and Haldane's dynamic simulations of a calibrated theoretical model, where the optimum lead length on the inflation forecast is found to lie between 3 and 6 quarters. However, in some key cases, as we shall see, different results emerge.

Lags of the dependent variable are always found to be significant. This is not surprising, as interest rate smoothing considerations appear to be a generally accepted part of monetary policy (see Almeida and Goodhart, 1996, Bernanke and Mihov, 1997, Goodhart, 1999). We detect a substantial amount of policy inertia in all the countries examined.

One difference between our approach in this paper and that in other studies is that we do not take for granted, or assume, any structural break in the behaviour of the monetary authorities. Also, we have not imposed any particular structure for any shifts in monetary policy. This is because we want to test whether any change can be detected in correspondence to announced regime shifts.

For this reason, we first estimated the reaction function (12) for each country over the full sample period - extending in the G3's case back to the end of Bretton Woods - and conducted a recursive analysis on the magnitude and the significance of regressors. Using structural stability tests we were then able to detect major breaks in interest rates policy. As most major shifts in interest-rate policies took place in the 1970s or early 1980 s, we then re-estimated a reaction function for each country over the post-1980 period, and again performed recursive tests and stability analysis. This allowed us to detect any parameter shifts in the reaction functions since 1980, and to interpret these shifts and any structural breaks in the light of announced institutional changes or shifts in policy regime.

Finally, as in Clarida et al. (1998), we allow for the possibility that the monetary authorities might have responded to other intermediate objectives not included in our baseline specification in (10). The reason for doing this is two-fold. First, if the baseline model did not perform well, we can check whether this is due to the targeting of some other intermediate objective. Second, institutional accounts of monetary policy suggest that these other variables 
might matter. Lagged values of money growth, changes in the exchange rates and influences from relevant foreign interest rates were included as additional regressors.

\subsection{Interest Rate Reaction Functions: the G3 countries}

We now turn to our empirical results. At the outset, our findings show how monetary institutions in the G3 (the U.S., Germany and Japan) have been remarkably stable during the sample period; i.e., the relationship between the political system and monetary institutions has not changed in these countries ${ }^{16}$. In the U.S. and Germany the central bank enjoys a relatively high degree of independence (see Cukierman 1992, Grilli et al., 1991) and is best defined as a "goal independent" central bank ${ }^{17}$, that is, a bank which is not held accountable for achieving a certain policy target. For instance German monetary policy has been defined as a regime of "disciplined discretion" (Laubach and Posen, 1997), whereas monetary policy during the Greenspan era has been defined as "pre-emptive monetary policy without an explicit nominal anchor" (Mishkin, 1997). An interesting issue which we examine is whether the success of the Fed in recent years has been achieved by changing the way in which interest rates respond to policy objectives.

Figure A.2 shows expected inflation and the ex ante real interest rates constructed using our measure of expected inflation for the G3. The importance of 1979 as a turning point for US monetary policy is evident, as real rates become positive after that date. Also, the contractionary policies of the early 1980s appear even stricter given the low level of inflationary expectations. This indicates a process of reputation building in inflation control.

Our estimated models are reported in Tables 1-7. For ease of exposition we report only the long-run static solutions of the model, as each regression contains one or two lags of the

\footnotetext{
${ }^{16}$ Since 1979, EMS membership might have constrained the Bundesbank's ability to retain control of monetary policy. Most discussions on the DM's role in the EMS have concluded that the Bundesbank largely retained her independence (see Fratianni and Von Hagen, 1990).

${ }^{17}$ For instance, both Neumann (1996) and Clarida and Gertler (1997) argue that the Bundesbank pursues multiple objectives and is flexible in attaining them, that is, emphasis sometimes shifts from one policy target to another. For a similar view see Mishkin and Posen (1997). For a contrasting view, stressing continuity in the Bundesbank's use of monetary targets, see Issing (1997).
} 
dependent variable. Asymptotic standard errors are reported for each estimated coefficient. Table 1 reports the estimated reaction function for Germany, respectively for the full sample period and since 1980. The estimates for the whole sample show that interest rates react to inflation expectations (with a point estimate greater than 1) and output. Adding the US Federal Funds rates marginally improves the fit of the interest rate reaction function ${ }^{18}$. Note that while the long run effect is only marginally significant, the Fed funds rate appears to be important in explaining the short-run dynamics of the German money market rate.The variable addition tests show that neither money growth nor the exchange rate (measured as the DM-US\$ rate) seems to exert an independent significant effect on German interest rates. This is interesting and confirms analogous results in Clarida and Gertler (1997), and Bernanke and Mihov (1997). Since 1971, the Bundesbank has set target ranges for the growth of broad monetary aggregates, but over the last fifteen years actual growth rates often exceeded (fell short of) the upper (lower) limit of the targeted band ${ }^{19}$. This confirms most modern accounts of the Bundesbank's monetary policy stance which suggest that monetary targets were not the Bank's primary objective but that discretionary undershoots and overshoots of the target bands were allowed where this did not impair the achievement of the inflationary objective.

The diagnostic tests for the estimated model in Table 1 shows some signs of nonnormality (and possibly ARCH) in the residuals, but this is due to the bunching of a small number of large residuals at the end of the 1970s, and this is apparent from the post-1980 estimates.

The estimated reaction function for Germany does not display any major shifts, with the estimated coefficients constant across sub-samples. We also found that a four-quarter lead for expected inflation works best for both the full sample and the post-1980 sample. Figure 1 shows 1-step and N-step down Chow tests, as well as the estimated coefficient and standard error bands and t-values for the expected inflation and output gap regressors for the post-1980 regression.

\footnotetext{
${ }^{18}$ For a descriptive account of these effects see Mishkin and Posen (1997).

19 See Von Hagen (1993), Issing (1997).
} 
The latter figure shows the long-run estimated coefficient as well as the asymptotic standard errors $^{20}$. This confirms the stability of the Bundesbank's policy rule, but shows that the size of the estimated response to the output gap fell after the unification shock in 1991. This shows, $\mathrm{n}$ line with recent work (Clarida et al., 1998), that monetary policy in Germany reacts systematically to cyclical conditions, even though the Bundesbank's declared monetary strategy (see Issing, 1997) is expressed in terms of monetary targets. Also, from 1980 onwards the overall policy thrust has gradually turned more conservative. Whilst 1980 does mark a watershed in monetary policy in Germany, our recursive estimates uncover a richer picture of gradual policy change.

Our estimates for the Japanese reaction function (Table 2) over the whole sample show an insignificant coefficient on the output gap, whereas that on expected inflation is significant but well below one. Furthermore, the equation performs poorly. We tried to improve on this by including additional regressors. It turns out that the US Federal Funds rate exerts a strong influence on Japanese policy. As in the case of the US (see the discussion below), instability in the reaction functions persists in the $1980-82$ period. Shortening the sample to the post-1982 period results in a dramatic increase in the expected inflation coefficient, which suggests that the central bank's attitude towards inflation changed markedly. On the other hand, the recursive estimates (Figure 2) show that cyclical conditions became important only after 1992. This confirms that in the 1980s Japanese monetary policy might have been hamstrung by agreements on managing the value of the US\$. It also confirms the casual observation that Japanese policy might not have been sufficiently geared towards domestic targets (see The Economist, July 17 1998), and that this might have contributed to the excessive deflation in Japan in the 1990s.

The USA reaction function estimated over the whole sample period (Table 3) is characterised by a coefficient on inflation which is not significantly larger than one and by a significant coefficient on the output gap. However, diagnostic tests and recursive graphics show a marked period of instability in the 1979-1982 period, when the Fed switched from interest rate

\footnotetext{
${ }^{20}$ These were computed using the authors' own GAUSS routines and plotted using GiveWin.
} 
targeting to monetary base targeting, which implied greater instability in money market rates. Since then, the Fed has opted for the targeting of money market (federal funds) rates ${ }^{21}$. Goodfriend (1995) argues that the 1979-1982 parenthesis of monetary base targeting also marked the Fed decision to aggressively clamp down on inflation expectations which was accomplished by 1985. Most existing accounts of US monetary policy suggests a stable environment post-1982. However, our recursive estimates show that this is not the case. The output coefficient has the wrong sign in the mid-1980s, suggesting that real interest rates were too low at a time when the output gap was positive. Only in the 1990s does the output coefficient sign become positive once more.

Our estimates over the post-1980 sample in Table 3 confirm that some important changes seem to have taken place. US policy does seem to have been less constant over time than Germany's. Interest rates seem to react to inflation expectations on a shorter horizon (a 2-quarter horizon is found to work best post-1985) and with a larger coefficient when the reaction function is re-estimated over the latter part of the sample. Our results reverse the conclusions of Clarida et al. (1998) using different estimation methods ${ }^{22}$, as they find an estimated coefficient on inflation which is much greater than one. The most intuitive explanation for this difference seems to lie in their chosen sample period, as we found that the size of our estimated inflation coefficient depends critically on the sample chosen. However, it may also depend critically on the chosen estimation method, as explained in Section 3.2.

The picture changes completely if we focus on the post-1985 sample (see Table 3). The equation is now stable, and includes a coefficient on expected inflation with a point estimate greater than unity (although it is not significantly larger than 1). The recursive graphs also

\footnotetext{
${ }^{21}$ For a detailed description of how techniques of monetary control have evolved in the U.S. see Lombra (1993).

${ }^{22}$ Mehra (1997) estimates a somewhat atheoretical reaction function, where the Fed funds rate follows an error correction process and responds to the output cycle and to the interest rate on long term treasury bills. We added the latter variable to our equation, but could not find any significant effect.
} 
confirm that in the 1990s the Fed was adjusting real rates to follow the output cycle much more closely $^{23}$. Figure 3 shows a significant output gap effect post-1991.

Overall, the Fed looks very different from the Bundesbank until the 1990s. On this point our results differ sharply from those of Clarida et al. (1998). The usual accounts suggest that, having successfully restrained inflation expectations in 1979-82, the Fed exploited her reputation to implement countercyclical policies. But the Fed's policy coefficients (particularly the output gap coefficient) suggest that a stable and correctly-signed reaction function only operated since the early 1990s. These findings also broadly illustrate a substantive difference between the Fed's and Bundesbank's monetary strategies.

The Bundesbank appears to respond more forcefully to movements in expected inflation than the Fed judging from the inflation expectation coefficient. Some authors have suggested that this result is open to other interpretations. Mishkin and Posen (1997) label the Fed policy as "just do it", or pre-emptive policy without a nominal anchor. Their argument is that monetary policy must act well in advance of a surge in inflation expectations since the full impact of monetary policy on inflation takes long lags. The main disadvantage of such a policy obviously lies in the difficulty of establishing a clear policy pattern with all the risks that this implies at times when the economy is being hit by major exogenous shocks. Our results suggest that such pragmatic and forward-looking policy should not be interpreted as if the Fed systematically reacted to longerterm expectations, as in the Bundesbank's case. In fact we found that shorter leads on the expected inflation variable ( 2 instead of 4 quarters) seemed to work better in the case of the US for the post-1985 sample. This confirms the casual observation that the Fed has chosen to signal its commitment to low inflation in recent years by reacting in advance to increases in inflationary expectations.

\footnotetext{
${ }^{23}$ One caveat emerges from the theoretical model discussed above: in a full information context, i.e. when the private sector has learned about the bank's preferences, inflation expectations are highly collinear with the output cycle. This might bias the estimated coefficient on the inflation expectations regressor downwards. On the other hand, we find only a very small correlation between our measures of expected inflation and the output gap. The
} 
The other key results from this section are as follows. First, the G3 policy reaction functions look very different. One size does not fit all, in sharp contrast to the view expressed by Dooley and Chinn (1997). Second, despite having stable institutions, monetary policymaking in the G3 seems to have evolved gradually in different directions: in Germany it appears to have become more conservative post-unification. In Japan, it seems to have been led astray by inappropriate external objectives, until recently. In the US, the highly successful countercyclical monetary policy of the Fed seems to be purely a 1990s phenomenon. These discrepancies are not apparent in the existing empirical literature because of the tendency to only report full-sample estimates for the 1980s.

\subsection{Interest Rate Reaction Functions: the inflation targeters}

Turning to the other countries in our sample, we shall relate our results to major changes in the way in which monetary policy was conducted. A variety of factors may cause shifts in estimated monetary policy reaction functions. Some of them, such as highly publicised institutional innovations and political changes are easily identified from descriptive accounts of monetary policy and will be discussed here. Other shifts in the reaction functions may have occurred for "technical" reasons. These include the instability of demand for money functions which eventually caused the demise of monetary aggregates. Similarly, in other countries the authorities may have relied (formally or informally) on indicators or intermediate objectives which were subsequently abandoned. These too are important in understanding our results, and will be discussed as they show up in our estimates

For most of the sample period, the central banks of the second group of countries(Canada, New Zealand, Sweden and the United Kingdom) have had limited independence in the conduct of monetary policy compared to the CBs of the G3 countries (see 
Cukierman, 1992, Grilli et al., 1991). During the 1990s explicit inflation targets were announced in all countries, but there are important differences within the group in terms of institutional arrangements and the role the central bank plays in achieving the target. In fact only New Zealand's CB (and to a lesser extent the UK's CB since 1997) has been given a legal mandate to achieve the inflation target.

In the UK, the Bank of England was only granted independence in 1997. However, there have been several changes in monetary strategy in the last two decades. The election of the Thatcher government in 1979 signalled a long-lasting shift in the collective attitude towards inflation $^{24}$. Instead of adopting an institutional approach the Conservative governments tried to build a reputation for their commitment to low inflation policies, experimenting first with monetary targets and then adopting a more eclectic approach to intermediate objectives from the mid-1980s. After a short spell of ERM membership in 1990-1992, the government then opted for a new monetary policy framework involving the announcement of formal inflation targets. The Conservative government chose not to delegate the implementation of monetary policy to an independent and accountable central bank. Instead the government's own reputation was the ultimate guarantee of the policy commitment. However, the central bank played the key role of publicly assessing the overall consistency of the policy stance ${ }^{25}$. The newly-elected Labour government in 1997 then sought to further bolster the inflation targeting framework by granting the Bank of England instrument independence. Monetary policy decisions are now taken by a newly-constituted Monetary Policy Committee.

Since the breakdown of M1 as an intermediate target in the early 1980s, until 1991 the Bank of Canada had not committed herself to any pre-determined policy pattern, apart from the reiteration of the long-term goal of price stability. Neither intermediate target nor time frame was apparently cast in the attempt to pursue the long-run objective, while various monetary and credit

\footnotetext{
24 Alogoskoufis et al. (1992) find convincing evidence of a spectacular reversal in the political business cycle after Mrs. Thatcher came to power. For a more descriptive analysis see Minford (1993).

${ }^{25}$ For a detailed account see Briault et al. (1995) and King (1998).
} 
aggregates (including the exchange rate with the US\$) were used in turn as information variables. In 1991 the government and the bank set a sequence of year-to-year target bands for the inflation rate, so as to bring about a gradual reduction in inflation. However, the $\mathrm{CB}$ was not granted a legislative mandate to achieve these inflation targets nor was a procedure established by which the CB would be held accountable for missing the targets. The "doctrine of dual responsibility" traditionally attributes the ultimate responsibility for the results of monetary policy to the Minister of Finance. Thus, the Bank of Canada has enjoyed only a limited degree of formal independence (see Grilli et al., 1991, Cukierman, 1992). Nonetheless, the monetary authorities had been publicly calling for a stricter control on inflation since 1988, while from 1994 the degree of transparency of their acts has remarkably increased (Mishkin and Posen, 1997).

Since 1977 Sweden had been pegging its currency unilaterally, first to a trade-weighted basket of currencies, then switching to the ECU in May 1991. However, the strength by which this commitment to the external anchor was pursued varied significantly, as numerous devaluations took place (Horngren and Lindberg, 1994). To some extent the Riksbank became less accommodating to inflation shocks after 1982. The marginal (overnight) rate was then extensively used to regulate large currency flows during the fixed exchange rate period. After the November 1992 crisis the Riksbank floated the Krona and announced the unilateral adoption of an inflation target in January $1993^{26}$. However the bank has never been granted an independent status, and political influences on the board are important (Svensson, 1995; McCallum, 1996).

Finally, we turn to the evolution of the monetary regime in New Zealand, which switched to inflation targeting in 1989. Historically, New Zealand's Reserve Bank had a degree of independence which ranked lowest amongst the OECD countries (see Grilli et al., 1991; Cukierman, 1992). Correspondingly, New Zealand's inflation rate was well above the OECD average. Up until the mid-1980s monetary policy relied mainly on regulation and administrative

\footnotetext{
${ }^{26}$ The term unilateral emphasises the lack of a legislative mandate to achieve a specific inflation target. See Svensson (1995) for a detailed account of these events.
} 
controls of capital markets. From 1985 the Bank turned to a more market-oriented approach to monetary control, and based policy decisions on a variety of indicators, such as the exchange rate, the term structure of interest rates, monetary aggregates and output (see Fischer, 1995). The Reserve Bank Act, introduced in 1990 to establish a legislative commitment to price stability, gave the Government and the Central Bank Governor the mandate to agree on a policy target (it was decided that this should be an inflation target), and explicitly contemplates the possibility of the Governor's dismissal if the set target is not met.

Figure A.3 plots the expected inflation series and the ex ante real interest rates computed using our expected inflation series for the group of inflation targeters in our study. It is interesting to note that in the case of Sweden, Canada and New Zealand ex ante real rates appear to have turned positive well before the announcement (represented in the charts as a vertical solid line) or the adoption of targets, while inflation expectations, at least in the first two countries, seem to have been somewhat subdued in proximity the announced regime changes.

In the case of UK, it is worth remembering that there were a number of changes in intermediate targets and in the techniques of monetary control since the 1970s. The first Thatcher government put an end to a phase of administrative controls on domestic credit expansion and on international capital movements, and put into place a commitment to money supply targets in the Medium-Term Financial Strategy (MTFS).

The MTFS envisaged amongst other things a 5-year sequence of gradually decelerating growth targets for £M3. However, the unstable relationship between this monetary aggregate and the final policy objectives quickly led to the demise of formal monetary targets. The government then adopted a more eclectic approach to targeting (see Minford, 1993, King, 1998), which basically involved targeting nominal income growth. In the late 1980s, the exchange rate assumed greater importance as an indicator of monetary conditions (see Bowen, 1995), and Sterling finally entered the ERM of the European Monetary System in 1990. The exit from ERM following the 1992 crisis forced the government to put an alternative regime in place, and the post-1992 
announcement of explicit inflation targets was seen as a practical way of achieving price stability, especially after the previous disappointments with monetary and exchange rate targets. It did not involve a new institutional regime until 1997 (as the government retained effective control of monetary policy throughout the period 1992-7), when the Bank of England was granted independence and became accountable for meeting the inflation target set by the government.

Our estimates for the UK (Table 4) show that over the whole sample period the coefficient on inflation expectations is not significantly larger than 1. Furthermore, the money market interest rate seems to have reacted to both the exchange rate and the money supply.

Given the instability in the estimated reaction function until the mid-1980s, we reestimated the equation for the 1985-1996 sample. This shows that the policy horizon became substantially shorter after the 1985 Sterling crisis- interest rates reacting to one-quarter ahead expected inflation - and the coefficient on expected inflation becomes significantly larger than one. Within this, the other minor shifts in policy regimes are also apparent (see Figure 4). For instance, the estimated coefficient on the sterling effective exchange rate was significant between 1988-1992, capturing both the 'shadowing the DM' and the ERM phases in UK policy. By contrast, the coefficients on the output gap became less significant during the ERM phase, as domestic policy objectives were sacrificed for the external objective.

All in all, our results closely mirror the changes in policy regimes outlined above. The main turning point is in 1979 . The more recent shifts in the estimated coefficients of the reaction function seem to be linked to the difficulties encountered in achieving a specific target rather than a lack of commitment to the goal of price stability.

Our estimates for Canada over the full sample period (1975-1997) yield somewhat puzzling results (see Table 5). When the US Fed funds rate is added to the equation, both the coefficients on the output gap and on expected inflation are not significant. Clearly, as in the case of Germany and Japan, the Fed funds rate absorbs part of the significance of the inflation 
variable. Even though M1 was the intermediate policy target in Canada between 1975 and $1982^{27}$ (Freedman,1995), we could not find a significant role for the money supply in our estimated reaction function. Furthermore, there are clear signs of instability in the estimated function in the late 1970 s and early 1980s. Re-estimating the equation for the post-1982 sample we find that the coefficient on inflation expectations is still insignificant, whereas effective exchange rate variations now seem to be significant alongside the Fed funds rate.

What about the impact of inflation targets? The introduction of targets does not seem to have caused a break in the behaviour of interest rate policy. At most there seems to have been a temporary impact on interest rate policy just prior to the introduction of inflation targets. Figure 5 shows some signs of instability in the expected inflation coefficient around the period 1990-1, although the N-step down Chow tests are not significant at the 5\% level. Descriptive accounts of Canadian monetary policy in this period (Mishkin and Posen, 1997) point out that the inflation target was used as a guidance for expectations, but stress that in several occasions monetary policy was in fact constrained to react to external conditions, such as exchange rate developments and the behaviour of US monetary policy.

Our estimated reaction function seems to confirm this. Furthermore, the Bank has recently defined a short-run operational target, the index of monetary conditions (MCI). MCI changes include variations in a short-term interest rate and in the trade-weighted exchange rate. Clearly, this highlights the importance of external constraints on the Bank of Canada's policy stance.

The full-sample estimates (1980-97) for Sweden show a significant but relatively low coefficient on expected inflation, while the output gap is not significant at all (see Table 6). The main instability in the estimated reaction function corresponds to the time of the ERM crisis in 1992. Monetary policy in Sweden has been externally tied to the ERM until 1992, when the krona was forced to devaluate notwithstanding an unprecedented surge in domestic interest rates.

\footnotetext{
${ }^{27}$ In 1982 it was officially abandoned due to innovations in the financial sector.
} 
Sweden has moved to inflation targeting since then. However, Svensson (1995) points out that the credibility of the new regime has been hampered by a number of factors, such as the deep political divisions over the conduct of monetary policy and the relatively large budget deficits. The sudden policy reversals and the overall uncertainty about the post-1992 regime clearly show up in our estimates, making it difficult to detect a clear policy pattern.

Once a dummy is included for the ERM crisis in 1992, the coefficient on expected inflation rises and becomes more significant, but the point estimate remains below one, and the output gap variable is almost significant at the $5 \%$ level. However, we are unable to find signs of a significant permanent shift in the reaction function following the introduction of inflation targets. The main story that emerges from Figure 6 is (as for the UK) the decreasing importance of domestic inflation and output targets just before the ERM crisis in 1992. On the other hand, since inflation did in fact fall in Sweden, one might conclude that monetary policy in this period is best defined as keeping real interest rates high until inflation was brought down. Taking into account the severe credibility constraints outlined above, this apparently stubborn policy was perhaps the only alternative left to the bank in order to signal her willingness to curb inflation.

New Zealand has been the most often cited inflation targeting experiment, not least because in this case the legal arrangements designed to regulate the bank activity follow the prescriptions of monetary policy design theory more closely than elsewhere (see Walsh, 1995). The estimated equation for the full sample (see Table 7, Figure 7) shows that interest rates seem to have reacted only to expected inflation - the estimated coefficient is close to be significantly larger than 1 - whereas domestic cyclical conditions do not seem to matter much ${ }^{28}$. Even though exchange rate shocks are explicitly cited in the Bank contract as a possible justification for deviating from the announced policy, we could not find a significant exchange rate effect. On the other hand diagnostic tests signal some $\mathrm{ARCH}$ pattern in the residuals. This may be due to

\footnotetext{
${ }^{28}$ Hutchison and Walsh (1998) suggested that the Reserve Bank looked at output stabilisation as an additional objective, but the output gap term is not significant in our estimates. Nevertheless, as pointed out previously, the absence of an output gap term in the reaction function does not preclude some degree of output stabilisation.
} 
occasional interest rate adjustments to external conditions. Another possible explanation is found in the exceedingly narrow band originally set around the inflation target, which caused significant instrument instability in a futile effort to "fine tune" inflation control ${ }^{29}$ (Mishkin and Posen, 1997). Once again, the key result from the stability tests is that in the '90s the Reserve Bank followed a policy pattern which was already been established in the former decade. The stability of the inflation expectations coefficient and of the overall equation indicates that the inflation target regime did not seem to make a marked difference to interest rate policy. The other main point to note is that inflation targeting does not seem to have allowed the authority a greater leeway to stabilise output fluctuations.

\section{Conclusions}

In this paper we estimate forward-looking interest rate reaction functions for the G3 economies and for a group of countries which recently adopted explicit inflation targets and central bank reforms as the centrepiece of their monetary strategies. In addition to the detailed results for each country set out above, a number of general conclusions emerge from our empirical results.

First, with the exception of the UK, the recent switch to inflation targets seems to have made little difference to interest rate policy in the group of inflation targeters. In practice it seems that any major changes in the responsiveness of interest rates to expected inflation took place well before the adoption of inflation targets or before the change towards greater central bank independence which occurred in some of these countries (New Zealand, Canada). The obvious conclusion is that the new regimes were brought in to consolidate gains in terms of lower inflation. Only time will tell if, in response to major exogenous shocks, monetary policy will respond more vigorously to inflationary forces than in the past. In the case of the UK we do

\footnotetext{
${ }^{29}$ Perhaps not surprisingly, both the inflation target and the band width were revised in the '90s
} 
detect a shift in policy stance as changes in targeting regimes took place. Since 1992, a stable reaction function seems to be in place.

Second, in countries where there were explicit intermediate targets (such as monetary aggregates in Germany) these are usually used as an anchor for expectations, but this does not necessarily imply that policy is strictly constrained to follow them in practice. Monetary policy often follows a broader set of objectives. Our results confirm those of previous researchers who find that in practice the Bundesbank targets inflation and output and reacts to external conditions.

Third, where the policy-maker is subject to some implicit constraint due to external conditions (as in the case of Canada and Japan) this can sometimes lead to a less clear picture regarding the monetary authorities' response to expected inflation and to the cycle.

Fourth, even in G3 countries where there have been no central bank or other institutional reforms (e.g. the US, Japan), we find that policies did evolve to a considerable degree in the 1980s and 1990s. Only since the 1990s do these countries begin to resemble the Bundesbank in terms of their estimated interest rate reaction functions.

Fifth, with the exception of Germany and the UK (since 1992), most of the monetary authorities in our sample do not seem to follow stable simple forward-looking policy reaction functions based on output gaps and expected inflation (and, a fortiori, Taylor rules). This suggests that caution has to be exercised in using an inflation targeting framework to model the preferences of the monetary authorities (see Clarida et al., 1998, Favero and Rovelli, 1999).

Finally, we should focus on some important differences in the behaviour of central banks regarding output stabilisation. On the one hand in the US we seem to have the apparent 'just do it' attitude of the Fed, who since 1990 exploits her reputation to focus on the cycle, bolstered to some extend by a shorter horizon on expected inflation in the estimated reaction function. At the other extreme there are those monetary authorities who feel that yet have to build up a reputation: e.g. the Swedish Riksbank's stubborn attempt to lower inflation expectations by means of high interest rates and the apparently exclusive focus of the Bank of New Zealand on 
domestic inflation. Whether this 'reputation-building' phase will also apply to central banks which have only recently acquired their independence, such as the Bank of England and the European Central Bank, remains an open question.

\section{References}

Alesina, A. and R. Gatti. (1995). "Independent central banks: low inflation at no cost?" American Economic Review, 85, 196-200.

Almeida, A. and C.A.E. Goodhart (1996). "Does the Adoption of Inflation Targets Affect Central Bank Behaviour?" London School of Economics, Financial Markets Group Working Paper, July.

al Nowaihi, A. and P. Levine (1996). "Independent but accountable: Walsh contracts and the credibility problem.” CEPR Discussion Paper \#1387.

Alogoskoufis, G., Lockwood B., and A. Philippopoulos (1992) 'Wage inflation, electoral uncertainty and the exchange rate regime - theory and UK evidence' Economic Journal, Vol.102, No.415, pp.1370-1394.

Bagliano, F.C., C. A. Favero. (1998). "Measuring monetary policy with VAR models: An evaluation". European Economic Review, 42, 6 ,1069-1112.

Bank of England, Inflation Report, various issues, London.

Baumgartner, J., R. Ramaswamy and G. Zettergren. (1997). "Monetary policy and leading indicators of inflation in Sweden." IMF Working Paper \# 34.

Bank of England (b), Bank of England Quarterly Bulletin, various issues, London.

Bernanke, B.S., and A. Blinder. (1992) " The Federal Funds Rate and the channels of monetary transmission." American Economic Review, 82, 901-21.

Bernanke, B.S. and I. Mihov (1995). “Measuring Monetary Policy”. NBER Working Paper \#5145.

Bernanke, B.S. and I. Mihov (1997). "What Does the Bundesbank Target?" European Economic Review, 41, 6, 1025-1053.

Bernanke, B.S., and F.S. Mishkin. (1997). "Inflation Targeting: A New Framework for Monetary Policy". Journal of Economic Perspectives, vol.11, no.2, 97-116. \#6157.

Bernanke, B.S. and M. Woodford. (1997). "Inflation forecasts and monetary policy." NBER Working Paper

Bowen, A. (1995) "British experience with inflation targetry". In Leiderman and Svensson (1995)

Broadbent, B. And Barro, R.J.. (1997). "Central Bank preferences and macroeconomic equilibrium." Journal of Monetary Economics, 39, 17-43.

Brunila, A. and H. Lahdenpera (1995). "Inflation targets: principal issues and practical implementation." In A. Haldane (ed.), Targeting Inflation, Bank of England, London.

Calvo, G.A. (1983) "Staggered prices in a utility-maximizing framework." Journal of Monetary Economics, 12, 383-398. (1997).

Campillo, M. and J.A. Miron. (1997). “Why does inflation differ across countries?”. In Romer and Romer 
Chinn, M.D. and M.P. Dooley. (1997) "Monetary Policy in Japan, Germany and the United States: does one size fit all?" NBER Working Paper \#6092. Romer (1997).

Clarida, R. and M. Gertler (1996). "How the Bundesbank Conducts Monetary Policy". In Romer and

Clarida, R., J. Gali, and M. Gertler (1998). "Monetary policy rules in practice: some international evidence". European Economic Review, vol. 42, no. 6, pp. 1033-1067.

Clarida, R., J. Gali, and M. Gertler (1997). “The Science of Monetary Policy” Mimeo

Christiano, L.J., M. Eichenbaum and C. L. Evans. (1994) “ Identification and the effects of monetary policy shocks.” Federal Reverve Bank of Chicago, working paper 94-7.

Christiano, L.J., M. Eichenbaum and C. L. Evans. (1998) "Monetary Policy Shocks: What Have We Learned and to What End?" NBER Working Paper \# 6400.

Cukierman, A. (1992). Central Bank Strategy, Credibility and Independence: Theory and Evidence. Cambridge MA MIT Press.

Cuthbertson, K, S. G. Hall, M. P. Taylor (1992). Applied econometric techniques. Phillip Allan: London

Dornbusch, R., C.A. Favero and F Giavazzi. (1998). "The immediate challenges for the European Central Bank.” NBER Working Paper \#6369.

Eichenbaum, M. and Evans, C. (1995). "Some empirical evidence on the effects of shocks to monetary policy on exchange rates", Quarterly Journal of Economics, Vol.110, No.4, pp.975-1009.

Favero, C. and Rovelli, R. (1999). "Modelling and identifying central banks' preferences" CEPR Discussion Paper $n$.

Faust, J. And L.E.O. Svensson (1998). “Transparency and credibility: monetary policy with unobservable goals." NBER Working Paper \#6452.

Fratianni, M.U., and D. Salvatore (eds) (1991). Monetary Policies in Developed Economies. Amsterdam, North-Holland.

Freedman, C. (1995) "The Canadian experience with targets for reducing and controlling inflation." In Leiderman and Svensson (1995).

Freeman, R.T. and J.L. Willis (1995). "Targeting Inflation in the 1990s: Recent Challenges.". Board of Governors of the Federal Reserve, International Finance Discussion Papers \# 525.

Harvey, A.C. (1989). Forecasting, Structural Time Series Models and the Kalman Filter. Cambridge University Press: Cambridge

Gaiotti, E., A. Gavosto and G. Grande (1997). "Inflation and Monetary Policy in Italy: Some Recent Evidence". Banca d'Italia, Temi di Discussione, No. 310.

Gerlach, S., and L.E.O. Svensson (1999) "Money and inflation in the Euro Area: a case for monetary indicators?" mimeo, IIES, Stockholm.

Goodfriend, M. (1995) "Acquiring and maintaining credibility for low inflation: the US experience". In Leiderman and Svensson (1995).

Goodhart, C.A.E. (1999). “Central bankers and uncertainty.' Bank of England Quarterly Bulletin, February 1999, pp.102-21.

Grilli, V., D. Masciandaro and G. Tabellini (1991). "Political and monetary institutions and public financial policies in the industrial countries". Economic Policy, October, pp. 342-92. 
Groeneveld, H., K.G., Koedijk and C.J.M. Kool (1996). "Inflation dynamics and monetary strategies: evidence from six industrialised countries.” Mimeo, University of Limburg, April.

Haldane, A.G. (ed.) (1995) Targeting Inflation. Bank of England.

Haldane, A.G. and N. Batini. (1998). "Forward-looking rules for monetary policy." NBER Working Paper \#6543.

Horngren, L., and H. Lindberg.(1994). "The struggle to turn the Swedish krona into a hard currency", in Akerholm and Giovannini (eds), Exchange rate policies in the Nordic Countries, CEPR, London.

Hutchison, M.M. and C.E. Walsh. (1998). "The output-inflation tradeoff and central bank reform: evidence from New Zealand". The Economic Journal, 108, 703-725.

Ichimura, S. (1993) “Japan”, in Fratianni and Salvatore (1993).

Issing. O. (1997). "Monetary targeting in Germany: the stability of monetary policy and of the monetary system”, Journal of Monetary Economics, Vol.39, No.1, pp.67-80

King, M. (1997). “The inflation target five years on.” Mimeo., Bank of England.

Laubach, T. and Posen, A,. (1997) "Some Comparative Evidence on the Effectiveness of Inflation Targeting." FRBNY Research Paper n.9714.

Leiderman, L. and L.E.O. Svensson (eds) (1995). Inflation Targets. London: CEPR.

Leeper, E.M., C.A. Sims and T. Zha (1996). "What Does Monetary Policy Do?”. Brookings Papers on Economic Activity, No. 2.

McCallum. B.T.. (1996). "Icrucial isues concerning central bank independence” NBER WP No 5597

McCallum. B.T.. (1997). "Issues in the design of monetary policy Rules.” NBER Working Paper \#6016.

McNees, S.K. (1992). “A forward-looking monetary policy reaction function: continuity and change." New England Economic Review, Nov/Dec., pp3-13.

Mehra, Y.P.. (1997). “A Federal Funds rate equation.” Economic Inquiry, XXXV, 621-630.

Melitz, J. (1997). "Some Cross-Country Evidence about Debt, Deficits and the Behaviour of Monetary and Fiscal Authorities". CEPR Discussion Paper \#1653.

Minford, P. (1993) “ The United Kingdom”, in Fratianni and Salvatore (1993)

Mishkin, F.S., and A.S. Posen (1997) “Inflation Targeting: Lessons from Four Countries”. NBER Working Paper \#6126.

Muscatelli, V.A. (1998a). "Optimal Inflation Contracts and Inflation Targets with Uncertain Central Bank Preferences: Accountability through Independence?” Economic Journal, 108, 529-542.

Muscatelli, V.A. (1998b). "Inflation Contracts and Inflation Targets under Uncertainty: Why we Might Need Conservative Central Bankers?” Economica, forthcoming.

Muscatelli, V.A., and P. Tirelli (1996) "Institutional change, inflation targets and the stability of interest rate functions in OECD economies.” University of Glasgow Dept. Of Economics Discussion Paper \# 9606.

Neumann, M.J.M. and J. von Hagen (1993). “Germany”, in Fratianni and Salvatore (1993).

Neuman, M.J.M. (1996) "Monetary Targeting in Germany". Paper prepared for the Bank of Japan $7^{\text {th }}$ International Conference. 
Persson, T. And G. Tabellini. (1997). "Political Economics and Macroeconomic Policy." CEPR Discussion Paper \#1759.

Posen, A. S., (1993). "Why central bank independence does not cause low inflation: there is no institutional fix for politics." In R.O' Brien, (ed.), Finance and the International Economy, Oxford University Press, pp. 4065.

Posen, A. S., (1995) Declarations are not enough: Financial sector services and central bank independence, in Bernanke, B., and J. Rotemberg, NBER Macroeconomics Annual, 1995 Cambridge MIT Press.

Romer, C.D., and D.H. Romer (eds.) (1997) Reducing Inflation: Motivation and Strategy. NBER, University of Chicago Press.

Rotemberg, J.J. (1983) "Supply shocks, sticky prices and monetary policy.” Journal of Money, Credit and Banking, 27(4) 975-984.

Rotemberg, J.J., and M. Woodford. (1998) "Interest-rate rules in an estimated sticky price model" NBER Working Paper \# 6618.

Rudebusch, G.D. (1995). 'Federal Reserve Interest Rate Targeting, Rational Expectations and the Term Structure." Journal of Monetary Economics, vol.35, pp.245-74.

Rudebusch, G.D. (1996). “Do Measures of Monetary Policy in a VAR Make Sense?” Banca d'Italia Discussion Paper n.269. \#6512.

Rudebusch, G.D. and L.E.O. Svensson. (1998). "Policy rules for inflation targeting." NBER Working Paper

Svensson, L.E.O. (1995). "The Swedish experience of an inflation target", in Leiderman and Svensson (1995).

Svensson, L.E.O. (1997a). "Optimal Inflation Targets, Conservative Central Banks and Linear Inflation Contracts.” American Economic Review, 87, 98-114.

Svensson, L.E.O. (1997b). "Inflation-forecast-targeting: implementing and monitoring inflation targets." European Economic Review. 41, 1111-1146.

Svensson, L.E.O. (1998). “Open-economy inflation targeting.” NBER Working Paper \#6545.

von Hagen, J. (1995). “Germany” in Leiderman and Svensson (1995).

Walsh, C. (1995). “Optimal Contracts for Central Bankers.” American Economic Review, 85, pp. 150-67.

Walsh, C. (1998). “Announcements, Inflation Targeting and Central Bank Incentives.”, Economica, forthcoming.

Woodford, M. (1996). “Control of the Public Debt: a Requirement for Price Stability?”. NBER Working Paper \#5684. 


\begin{tabular}{|c|c|c|c|c|c|c|c|c|}
\hline \multirow[t]{2}{*}{$\begin{array}{l}\text { Sample } \\
\text { Regressor }\end{array}$} & \multicolumn{4}{|c|}{ 1970Q3-1996Q4 } & \multicolumn{4}{|c|}{ 1980Q1-1996Q4 } \\
\hline & \multicolumn{2}{|c|}{ Baseline* } & \multicolumn{2}{|c|}{$\begin{array}{c}\text { Adding } \\
\text { Fed Funds Rate** }\end{array}$} & \multicolumn{2}{|c|}{ Baseline* } & \multicolumn{2}{|c|}{$\begin{array}{c}\text { Adding } \\
\text { Fed Funds Rate** }\end{array}$} \\
\hline Constant & \multicolumn{2}{|c|}{$\begin{array}{c}0.01284 \\
(0.01498)\end{array}$} & \multicolumn{2}{|c|}{$\begin{array}{c}-0.002516 \\
(0.01731)\end{array}$} & \multicolumn{2}{|c|}{$\begin{array}{c}0.02088 \\
(0.00818)\end{array}$} & \multicolumn{2}{|c|}{$\begin{array}{l}0.007248 \\
(0.01178)\end{array}$} \\
\hline $\begin{array}{l}\text { Expected } \\
\text { Inflation }\end{array}$ & \multicolumn{2}{|c|}{$\begin{array}{c}1.416 \\
(0.3835)\end{array}$} & \multicolumn{2}{|c|}{$\begin{array}{c}1.174 \\
(0.3255)\end{array}$} & \multicolumn{2}{|c|}{$\begin{array}{c}1.494 \\
(0.2434)\end{array}$} & \multicolumn{2}{|c|}{$\begin{array}{c}1.373 \\
(0.2602)\end{array}$} \\
\hline $\begin{array}{l}\text { Output } \\
\text { Gap }\end{array}$ & \multicolumn{2}{|c|}{$\begin{array}{c}0.9186 \\
(0.4643)\end{array}$} & \multicolumn{2}{|c|}{$\begin{array}{c}0.8073 \\
(0.3999)\end{array}$} & \multicolumn{2}{|c|}{$\begin{array}{c}0.4848 \\
(0.2351)\end{array}$} & \multicolumn{2}{|c|}{$\begin{array}{l}0.6077 \\
(0.263)\end{array}$} \\
\hline $\begin{array}{l}\text { Fed Funds } \\
\text { Rate }\end{array}$ & & & \multicolumn{2}{|c|}{$\begin{array}{c}0.3144 \\
(0.1702)\end{array}$} & & & \multicolumn{2}{|c|}{$\begin{array}{c}0.21 \\
(0.1175)\end{array}$} \\
\hline $\begin{array}{l}\text { Variable } \\
\text { Addition } \\
\text { Tests*** }\end{array}$ & $\begin{array}{l}\text { money growth } \\
\text { exchange rate }\end{array}$ & $\begin{array}{l}1.2556[0.2895] \\
1.2552[0.2948]\end{array}$ & & & $\begin{array}{l}\text { money growth } \\
\text { exchange rate }\end{array}$ & $\begin{array}{l}0.56493[0.5713] \\
0.71692[0.5457]\end{array}$ & & \\
\hline $\begin{array}{l}\text { Summary } \\
\text { Statistics }\end{array}$ & $\begin{array}{l}R^{2} \\
\sigma \\
D W \\
A R 1-5 F(5,97) \\
\text { ARCH } 4 \quad F(4,94) \\
\text { Normality } \chi^{2}(2) \\
\text { RESET } F(1,101)\end{array}$ & $\begin{array}{l}0.870249 \\
0.009158 \\
1.73 \\
1.2563[0.2891] \\
3.3586[0.0129] \\
55.873[0.0000] \\
0.4661[0.4963] \\
\end{array}$ & $\begin{array}{l}R^{2} \\
\sigma \\
D W \\
A R 1-5 F(5,95) \\
\text { ARCH 4 F } 4,92) \\
\text { Normality } \chi^{2}(2) \\
\text { RESET } F(1,99)\end{array}$ & $\begin{array}{l}0.8908 \\
0.008485 \\
1.80 \\
1.4545[0.2121] \\
2.3624[0.0588] \\
65.731[0.0000] \\
1.2401[0.2682] \\
\end{array}$ & $\begin{array}{l}R^{2} \\
\sigma \\
D W \\
\text { AR } 1-5 F(5,59) \\
\text { ARCH 4 F( 4,56) } \\
\text { Normality } \chi^{2}(2) \\
\text { RESET } F(1,63)\end{array}$ & $\begin{array}{l}0.949219 \\
0.0055634 \\
1.69 \\
0.7215[0.6100] \\
0.4445[0.7759] \\
11.187[0.0037] \\
0.0168[0.8971] \\
\end{array}$ & $\begin{array}{l}R^{2} \\
\sigma \\
D W \\
\text { AR } 1-5 F(5,57) \\
\text { ARCH } 4 \quad F(4,54) \\
\text { Normality } \chi^{2}(2) \\
\text { RESET } F(1,61) \\
\end{array}$ & $\begin{array}{l}0.963906 \\
0.00476544 \\
1.60 \\
2.0422[0.0863] \\
1.4412[0.2330] \\
0.3125[0.8554] \\
0.0301[0.8627] \\
\end{array}$ \\
\hline
\end{tabular}

\section{Table 1. Germany}

*Derived from a RLS regression of the interest rate on a constant, 4-quarter ahead expected inflation, output gap and one lag of the dependent variable.

**As for the note above, but now with two lags of the Fed Funds Rate on the RHS.

***We tested for the addition of other regressors. Zero restrictions on lagged money growth and changes in the current and lagged exchange rate vis-a-vis the US\$ were tested by a F-version of the Wald test. P-values in brackets.

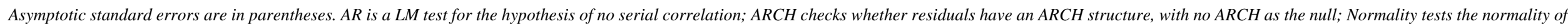
residuals; RESET tests the null of no functional mis-specification. P-values in brackets. 


\begin{tabular}{|c|c|c|c|c|c|c|c|c|}
\hline \multirow[t]{2}{*}{$\begin{array}{l}\text { Sample } \\
\text { Regressor }\end{array}$} & \multicolumn{4}{|c|}{ 1971Q4-1996Q3 } & \multicolumn{4}{|c|}{ 1982Q1-1996Q3 } \\
\hline & \multicolumn{2}{|c|}{ Baseline* } & \multicolumn{2}{|c|}{$\begin{array}{c}\text { Adding } \\
\text { Fed Funds Rate** }\end{array}$} & \multicolumn{2}{|c|}{ Baseline* $^{*}$} & \multicolumn{2}{|c|}{$\begin{array}{c}\text { Adding } \\
\text { Fed Funds Rate }{ }^{* *}\end{array}$} \\
\hline Constant & \multicolumn{2}{|c|}{$\begin{array}{c}0.03263 \\
(0.01081)\end{array}$} & \multicolumn{2}{|c|}{$\begin{array}{l}-0.01123 \\
(0.01276)\end{array}$} & \multicolumn{2}{|c|}{$\begin{array}{l}-7.478 \\
(2.538)\end{array}$} & \multicolumn{2}{|c|}{$\begin{array}{l}-0.02378 \\
(0.01929)\end{array}$} \\
\hline $\begin{array}{l}\text { Expected } \\
\text { Inflation }\end{array}$ & \multicolumn{2}{|c|}{$\begin{array}{l}0.6292 \\
(0.1894)\end{array}$} & \multicolumn{2}{|c|}{$\begin{array}{c}0.4389 \\
(0.09508)\end{array}$} & \multicolumn{2}{|c|}{$\begin{array}{c}1.872 \\
(0.6319)\end{array}$} & \multicolumn{2}{|c|}{$\begin{array}{c}1.821 \\
(0.5251)\end{array}$} \\
\hline $\begin{array}{l}\text { Output } \\
\text { Gap }\end{array}$ & \multicolumn{2}{|c|}{$\begin{array}{c}0.791 \\
(0.5732)\end{array}$} & \multicolumn{2}{|c|}{$\begin{array}{l}-0.03604 \\
(0.3074)\end{array}$} & \multicolumn{2}{|c|}{$\begin{array}{c}1.22 \\
(0.7698)\end{array}$} & \multicolumn{2}{|c|}{$\begin{array}{c}0.8286 \\
(0.5059)\end{array}$} \\
\hline $\begin{array}{l}\text { Fed Funds } \\
\text { Rate }\end{array}$ & & & & & & & & $\begin{array}{l}548 \\
044)\end{array}$ \\
\hline $\begin{array}{l}\text { Variable } \\
\text { Addition } \\
\text { Tests*** }\end{array}$ & $\begin{array}{l}\text { money growth } \\
\text { exchange rate }\end{array}$ & $\begin{array}{l}1.3935[0.2533] \\
2.4543[0.0684]\end{array}$ & & & $\begin{array}{l}\text { money growth } \\
\text { exchange rate }\end{array}$ & $\begin{array}{l}0.29414[0.7464] \\
0.6417[0.5917]\end{array}$ & & \\
\hline $\begin{array}{l}\text { Summary } \\
\text { Statistics }\end{array}$ & $\begin{array}{l}R^{2} \\
\sigma \\
D W \\
A R 1-5 F(5,90) \\
\text { ARCH } 4 F(4,87) \\
\text { Normality } \chi^{2}(2) \\
\operatorname{RESET~} F(1,94) \\
\end{array}$ & $\begin{array}{l}0.952320 .00639043 \\
2.24 \\
3.1778[0.0109] \\
2.1103[0.0863] \\
25.49[0.0000] \\
4.189[0.0435]\end{array}$ & $\begin{array}{l}R^{2} \\
\sigma \\
D W \\
A R 1-5 F(5,89) \\
\text { ARCH } 4 \quad F(4,86) \\
\text { Normality } \chi^{2}(2) \\
\text { RESET } F(1,93)\end{array}$ & $\begin{array}{l}0.960445 \\
0.00585134 \\
2.17 \\
1.447[0.2154] \\
2.4588[0.0514] \\
9.3293[0.0094] \\
1.7085[0.1944] \\
\end{array}$ & $\begin{array}{l}R^{2} \\
\sigma \\
D W \\
A R 1-5 F(5,53) \\
\text { ARCH } 4 \quad F(4,50) \\
\text { Normality } \chi^{2}(2) \\
\text { RESET } F(1,57)\end{array}$ & $\begin{array}{l}0.971225 \\
0.00412458 \\
1.90 \\
0.2559[0.9350] \\
8.2479[0.0000] \\
5.1598[0.0758] \\
3.2564[0.0764] \\
\end{array}$ & $\begin{array}{l}R^{2} \\
\sigma \\
D W \\
A R 1-5 F(5,48) \\
\text { ARCH 4 F( 4, 45) } \\
\text { Normality } \chi^{2}(2) \\
\text { RESET } F(1,52)\end{array}$ & $\begin{array}{l}0.969527 \\
0.00398603 \\
2.03 \\
0.46784[0.7983] \\
3.5538[0.0133] \\
6.9901[0.0303] \\
0.092264[0.7625] \\
\end{array}$ \\
\hline
\end{tabular}

\section{Table 2. Japan}

*Derived from a RLS regression of the interest rate on a constant, 4-quarter ahead expected inflation, output gap and two lags of the dependent variable.

**As for the note above, but now with one lag of the Fed Funds Rate on the RHS.

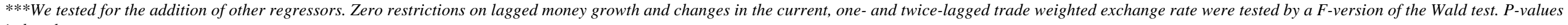
in brackets.

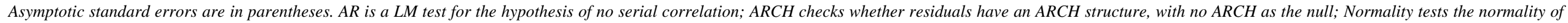
residuals; RESET tests the null of no functional mis-specification. P-values in brackets. 


\begin{tabular}{|c|c|c|c|c|c|c|}
\hline $\begin{array}{l}\text { Sample } \\
\text { Regressor }\end{array}$ & \multicolumn{2}{|c|}{$1971 Q 4-1996 Q 3 *$} & 1980 & 996Q3* & \multicolumn{2}{|c|}{$1985 Q 1-1996 Q 3 * *$} \\
\hline Constant & \multirow{2}{*}{\multicolumn{2}{|c|}{$\begin{array}{c}0.02213 \\
(0.02348) \\
\\
1.18 \\
(0.4148)\end{array}$}} & \multirow{2}{*}{\multicolumn{2}{|c|}{$\begin{array}{c}0.006149 \\
(0.02366) \\
\\
1.81 \\
(0.5315)\end{array}$}} & \multirow{2}{*}{\multicolumn{2}{|c|}{$\begin{array}{c}0.02422 \\
(0.007616) \\
\\
1.079 \\
(0.2148)\end{array}$}} \\
\hline $\begin{array}{l}\text { Expected } \\
\text { Inflation }\end{array}$ & & & & & & \\
\hline $\begin{array}{l}\text { Output } \\
\text { Gap }\end{array}$ & \multicolumn{2}{|c|}{$\begin{array}{c}1.572 \\
(0.7553)\end{array}$} & & & \multicolumn{2}{|c|}{$\begin{array}{c}0.9266 \\
(0.1387)\end{array}$} \\
\hline $\begin{array}{l}\text { Variable } \\
\text { Addition } \\
\text { Tests*** }\end{array}$ & $\begin{array}{l}\text { money growth } \\
\text { exchange rate }\end{array}$ & $\begin{array}{l}0.02210[0.9781] \\
1.1505[0.3211]\end{array}$ & $\begin{array}{l}\text { money growth } \\
\text { exchange rate }\end{array}$ & $\begin{array}{l}0.04188[0.9590] \\
0.36603[0.6950]\end{array}$ & $\begin{array}{l}\text { money growth } \\
\text { exchange rate }\end{array}$ & $\begin{array}{l}0.05796[0.9438] \\
0.11224[0.8941]\end{array}$ \\
\hline $\begin{array}{l}\text { Summary } \\
\text { Statistics }\end{array}$ & $\begin{array}{l}R^{2} \\
\sigma \\
D W \\
\text { AR } 1-5 F(5,90) \\
\text { ARCH } 4 \quad F(4,87) \\
\text { Normality } \chi^{2}(2) \\
\text { RESET } F(1,94)\end{array}$ & $\begin{array}{l}0.8112530 .0151201 \\
2.14 \\
5.0224[0.0004] \\
15[0.0000] \\
63.106[0.0000] \\
0.38632[0.5357]\end{array}$ & $\begin{array}{l}R^{2} \\
\sigma \\
D W \\
\text { AR } 1-5 F(5,57) \\
\text { ARCH } 4 \quad F(4,54) \\
\text { Normality } \chi^{2}(2) \\
\text { RESET } F(1,61)\end{array}$ & $\begin{array}{l}0.814444 \\
0.0165079 \\
2.19 \\
3.42[0.0090] \\
17.675[0.0000] \\
65.253[0.0000] \\
1.6571[0.2029]\end{array}$ & $\begin{array}{l}R^{2} \\
\sigma \\
D W \\
A R 1-5 F(5,40) \\
\text { ARCH } 4 \quad F(4,37) \\
\text { Normality } \chi^{2}(2) \\
\text { RESET } F(1,44)\end{array}$ & $\begin{array}{l}0.950583 \\
0.00440362 \\
1.95 \\
0.76539[0.5802] \\
0.48356[0.7476] \\
2.9124[0.2331] \\
8.28 e-007[0.999]\end{array}$ \\
\hline
\end{tabular}

\section{Table 3. USA}

*Derived from a RLS regression of the interest rate on a constant, 4-quarter ahead expected inflation, output gap and two lags of the dependent variable.

** Derived from a RLS regression of the interest rate on a constant, 2-quarter ahead expected inflation, output gap and one lag of the dependent variable.

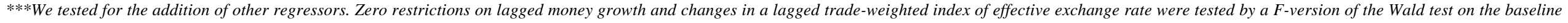
model augmented of each new variable. $P$-values in brackets.

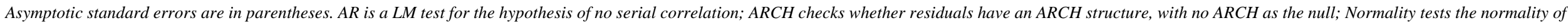
residuals; RESET tests the null of no functional mis-specification. P-values in brackets. 


\begin{tabular}{|c|c|c|c|c|c|c|c|c|}
\hline \multirow[t]{2}{*}{$\begin{array}{l}\text { Sample } \\
\text { Regressor }\end{array}$} & \multicolumn{4}{|c|}{$1975 Q 3-1996 Q 3$} & \multicolumn{2}{|c|}{ 1980Q1-1996Q3 } & \multicolumn{2}{|c|}{$1985 Q 1-1996 Q 3$} \\
\hline & \multicolumn{2}{|c|}{ Baseline* } & \multicolumn{2}{|c|}{ Adding Exchange Rate ${ }^{* *}$} & & $n e^{*}$ & \multicolumn{2}{|c|}{ Baseline $^{* * *}$} \\
\hline Constant & \multicolumn{2}{|c|}{$\begin{array}{c}0.04062 \\
(0.02056)\end{array}$} & \multicolumn{2}{|c|}{$\begin{array}{c}0.02662 \\
(0.02697)\end{array}$} & \multicolumn{2}{|c|}{$\begin{array}{c}0.0393 \\
(0.0187)\end{array}$} & \multicolumn{2}{|c|}{$\begin{array}{c}0.02367 \\
(0.01275)\end{array}$} \\
\hline $\begin{array}{l}\text { Expected } \\
\text { Inflation }\end{array}$ & \multicolumn{2}{|c|}{$\begin{array}{c}0.9088 \\
(0.2821)\end{array}$} & \multicolumn{2}{|c|}{$\begin{array}{l}1.117 \\
(0.3775)\end{array}$} & \multicolumn{2}{|c|}{$\begin{array}{l}1.087 \\
(0.322)\end{array}$} & \multicolumn{2}{|c|}{$\begin{array}{c}1.403 \\
(0.2831)\end{array}$} \\
\hline $\begin{array}{l}\text { Output } \\
\text { Gap } \\
\text { Exchange } \\
\text { Rate } \\
\end{array}$ & \multicolumn{2}{|c|}{$\begin{array}{c}0.8017 \\
(0.3672)\end{array}$} & \multicolumn{2}{|c|}{$\begin{array}{c}0.9981 \\
(0.4593) \\
-0.6601 \\
(0.3609)\end{array}$} & & & \multicolumn{2}{|c|}{$\begin{array}{c}0.6388 \\
(0.1987)\end{array}$} \\
\hline $\begin{array}{l}\text { Variable } \\
\text { Addition } \\
\text { Tests } * * * *\end{array}$ & $\begin{array}{l}\text { M4 growth } \\
\text { M1 growth } \\
\text { exchange rate } \\
\text { German rate }\end{array}$ & $\begin{array}{l}2.2368[0.1135] \\
2.4012[0.0972] \\
2.5803[0.0595] \\
3.598[0.0173] \\
\end{array}$ & & & $\begin{array}{l}\text { money growth } \\
\text { exchange rate } \\
\text { German rate }\end{array}$ & $\begin{array}{l}0.84828[0.4331] \\
1.565[0.2072] \\
1.5552[0.2096]\end{array}$ & $\begin{array}{l}\text { moneygrowth } \\
\text { exchange rate } \\
\text { German rate }\end{array}$ & $\begin{array}{l}4.7366[0.0141] \\
2.0764[0.1186] \\
3.7459[0.0184]\end{array}$ \\
\hline $\begin{array}{l}\text { Summary } \\
\text { Statistics }\end{array}$ & $\begin{array}{l}R^{2} \\
\sigma \\
D W \\
A R 1-5 F(5,76) \\
\text { ARCH } 4 \quad F(4,73) \\
\text { Normality } \chi^{2}(2) \\
\text { RESET } F(1,80) \\
\end{array}$ & $\begin{array}{l}0.867889 \\
0.011124 \\
1.67 \\
0.81065[0.5457] \\
1.6248[0.1772] \\
7.1475[0.0281] \\
0.0955[0.7581] \\
\end{array}$ & $\begin{array}{l}R^{2} \\
\sigma \\
D W \\
\text { AR } 1-5 F(5,75) \\
\text { ARCH } 4 \quad F(4,72) \\
\text { Normality } \chi^{2}(2) \\
\text { RESET } F(1,79) \\
\end{array}$ & $\begin{array}{l}0.878873 \\
0.0107179 \\
1.58 \\
1.1024[0.3664] \\
0.98115[0.4233] \\
5.4778[0.0646] \\
0.18972[0.6643] \\
\end{array}$ & $\begin{array}{l}R^{2} \\
\sigma \\
D W \\
\text { AR } 1-5 F(5,58) \\
\text { ARCH } 4 \quad F(4,55) \\
\text { Normality } \chi^{2}(2) \\
\text { RESET } F(1,62) \\
\end{array}$ & $\begin{array}{l}0.904109 \\
0.00982599 \\
1.74 \\
0.83746[0.5286] \\
1.2151[0.3150] \\
8.6269[0.0134] \\
1.2575[0.2664] \\
\end{array}$ & $\begin{array}{l}R^{2} \\
\sigma \\
D W \\
\text { AR } 1-5 F(5,38) \\
\text { ARCH } 4 \quad F(4,35) \\
\text { Normality } \chi^{2}(2) \\
\text { RESET } F(1,42) \\
\end{array}$ & $\begin{array}{l}0.93223 \\
0.00844755 \\
1.27 \\
2.3838[0.0563] \\
1.8764[0.1365] \\
12.864[0.0016] \\
2.4368[0.1260] \\
\end{array}$ \\
\hline
\end{tabular}

\section{Table 4. United Kingdom}

*Derived from a RLS regression of the interest rate on a constant, 4-quarter ahead expected inflation, output gap and one lag of the dependent variable.

**Derived from a RLS regression of the interest rate on a constant, 4-quarter ahead expected inflation, output gap and the current trade-weighted index of effective exchange rate.

***Derived from a RLS regression of the interest rate on a constant, one-quarter ahead expected inflation, output gap and one lag of the dependent variable.

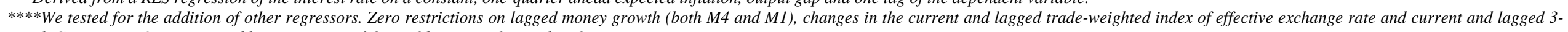
month German FIBOR were tested by a F-version of the Wald test. P-values in brackets. 


\begin{tabular}{|c|c|c|c|c|c|c|}
\hline $\begin{array}{l}\text { Sample } \\
\text { Regressor }\end{array}$ & \multicolumn{2}{|c|}{$1975 Q 3-1996 Q 2$} & \multicolumn{2}{|c|}{$1975 Q 3-1996 Q 2$} & \multicolumn{2}{|c|}{ 1982Q1-1996Q2 } \\
\hline & \multicolumn{2}{|c|}{ Baseline* $^{*}$} & \multicolumn{2}{|c|}{ Adding Federal Funds Rate** } & \multicolumn{2}{|c|}{ Adding Federal Funds Rate**** } \\
\hline Constant & \multirow{2}{*}{\multicolumn{2}{|c|}{$\begin{array}{c}0.04624 \\
(0.01912) \\
\\
1.036 \\
(0.3289)\end{array}$}} & \multicolumn{2}{|c|}{$\begin{array}{c}0.01807 \\
(0.00929)\end{array}$} & \multicolumn{2}{|c|}{$\begin{array}{c}0.02178 \\
(0.007424)\end{array}$} \\
\hline $\begin{array}{l}\text { Expected } \\
\text { Inflation }\end{array}$ & & & \multicolumn{2}{|c|}{$\begin{array}{c}0.007358 \\
(0.1505)\end{array}$} & \multicolumn{2}{|c|}{$\begin{array}{c}0.2022 \\
(0.2541)\end{array}$} \\
\hline $\begin{array}{l}\text { Output } \\
\text { Gap }\end{array}$ & \multicolumn{2}{|c|}{$\begin{array}{c}0.6367 \\
(0.5969)\end{array}$} & \multicolumn{2}{|c|}{$\begin{array}{l}0.3783 \\
(0.209)\end{array}$} & \multicolumn{2}{|c|}{$\begin{array}{c}0.224 \\
(0.1501)\end{array}$} \\
\hline $\begin{array}{l}\text { Fed Funds } \\
\text { Rate }\end{array}$ & & & \multicolumn{2}{|c|}{$\begin{array}{c}1.009 \\
(0.1523)\end{array}$} & \multicolumn{2}{|c|}{$\begin{array}{l}0.8696 \\
(0.161)\end{array}$} \\
\hline $\begin{array}{l}\text { Variable } \\
\text { Addition } \\
\text { Tests } * * * *\end{array}$ & $\begin{array}{l}\text { money growth } \\
\text { exchange rate }\end{array}$ & $\begin{array}{l}1.168[0.3164] \\
0.54758[0.6513]\end{array}$ & & & exchange rate & $3.2878[0.0281]$ \\
\hline $\begin{array}{l}\text { Summary } \\
\text { Statistics }\end{array}$ & $\begin{array}{l}R^{2} \\
\sigma \\
D W \\
\text { AR } 1-4 F(4,72) \\
\text { ARCH } 4 \quad F(4,68) \\
\text { Normality } \chi^{2}(2) \\
\text { RESET } F(1,75)\end{array}$ & $\begin{array}{l}0.7408680 .0184464 \\
1.98 \\
0.10383[0.9808] \\
6.6823[0.0001] \\
20.536[0.0000] \\
0.02468[0.8756]\end{array}$ & $\begin{array}{l}R^{2} \\
\sigma \\
D W \\
A R 1-4 F(4,74) \\
\text { ARCH 4 } F(4,70) \\
\text { Normality } \chi^{2}(2) \\
\text { RESET } F(1,77)\end{array}$ & $\begin{array}{l}0.818641 \\
0.0152328 \\
2.32 \\
6.8396[0.0001] \\
7.2532[0.0001] \\
4.1906[0.1230] \\
0.3653[0.5473]\end{array}$ & $\begin{array}{l}R^{2} \\
\sigma \\
D W \\
A R 1-4 F(4,47) \\
\text { ARCH } 4 \quad F(4,43) \\
\text { Normality } \chi^{2}(2) \\
\text { RESET } F(1,50)\end{array}$ & $\begin{array}{l}0.907322 \\
0.00879038 \\
1.96 \\
0.37725[0.8237] \\
1.9921[0.1128] \\
0.75685[0.6849] \\
0.14571[0.7043]\end{array}$ \\
\hline
\end{tabular}

\section{Table 5. Canada}

*Derived from a RLS regression of the interest rate on a constant, 4-quarter ahead expected inflation, output gap and two lags of the dependent variable.

**Derived from a RLS regression of the interest rate on a constant, 4-quarter ahead expected inflation, output gap, two lags of the dependent variable and the current Fed Funds Rate.

***Derived from a RLS regression of the interest rate on a constant, 4-quarter ahead expected inflation, current and lagged output gap, one lag of the dependent variable and current Fed Funds Rate.

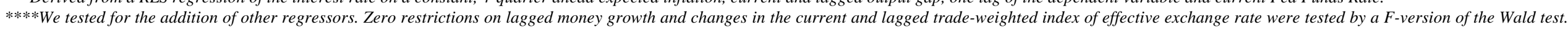
$P$-values in brackets. 


\begin{tabular}{|c|c|c|c|c|}
\hline \multirow[t]{2}{*}{$\begin{array}{l}\text { Sample } \\
\text { Regressor }\end{array}$} & \multicolumn{4}{|c|}{ 1982Q3-1997Q2 } \\
\hline & & & & $\begin{array}{l}\text { ling } \\
\text { immy** }\end{array}$ \\
\hline Constant & & & & 238 \\
\hline $\begin{array}{l}\text { Expected } \\
\text { Inflation }\end{array}$ & & & & $\begin{array}{l}111 \\
471)\end{array}$ \\
\hline $\begin{array}{l}\text { Output } \\
\text { Gap }\end{array}$ & & & & $\begin{array}{l}461 \\
389)\end{array}$ \\
\hline $\begin{array}{l}\text { ERM } \\
\text { dummy }\end{array}$ & & & & 4841 \\
\hline $\begin{array}{l}\text { Variable } \\
\text { Addition } \\
\text { Tests*** }\end{array}$ & & & $\begin{array}{l}\text { money growth } \\
\text { exchange rate } \\
\text { German rate }\end{array}$ & $\begin{array}{l}2.3225[0.1079] \\
1.6609[0.1868] \\
2.5539[0.0654]\end{array}$ \\
\hline $\begin{array}{l}\text { Summary } \\
\text { Statistics }\end{array}$ & $\begin{array}{l}R^{2} \\
\sigma \\
D W \\
A R 1-4 F(4,52) \\
\text { ARCH } 4 \quad F(4,48) \\
\text { Normality } \chi^{2}(2) \\
\text { RESET } F(1,55)\end{array}$ & $\begin{array}{l}0.826297 \\
0.0117457 \\
1.66 \\
2.2564[0.0755] \\
0.26744[0.8975] \\
10.808[0.0045] \\
3.463[0.0681] \\
\end{array}$ & $\begin{array}{l}R^{2} \\
\sigma \\
D W \\
A R 1-4 F(4,51) \\
\text { ARCH } 4 \quad F(4,47) \\
\text { Normality } \chi^{2}(2) \\
\text { RESET } F(1,54)\end{array}$ & $\begin{array}{l}.852995 \\
.01091 \\
1.42 \\
3.288[0.018] \\
2.653[0.044] \\
2.238[0.327] \\
3.48[0.0676]\end{array}$ \\
\hline
\end{tabular}

\section{Table 6. Sweden}

*Derived from a RLS regression of the interest rate on a constant, one-quarter ahead expected inflation, output gap and one lag of the dependent variable.

**Derived from a RLS regression of the interest rate on a constant, one-quarter ahead expected inflation, output gap and a dummy variable assuming value one in the third and fourth quarter on 1992 and zero elsewhere, and one lag of the dependent variable.

***We tested for the addition of other regressors. Zero restrictions on lagged money growth, changes in the current and lagged trade-weighted index of effective exchange rate and current and lagged 3-month German FIBOR were tested by a F-version of the Wald test. P-values in brackets.

Asymptotic standard errors are in parentheses. AR is a LM test for the hypothesis of no serial correlation; ARCH checks whether residuals have an ARCH structure, with no ARCH as the null; Normality tests the normality of residuals; RESET tests the null of no functional mis-specification. Pvalues in brackets. 


\begin{tabular}{|c|c|c|c|c|}
\hline $\begin{array}{l}\text { Sample } \\
\text { Regressor }\end{array}$ & \multicolumn{2}{|c|}{$1982 Q 4-1997 Q 2 *$} & \multicolumn{2}{|c|}{$1982 Q 4-1997 Q 1 * *$} \\
\hline Constant & \multicolumn{2}{|c|}{$\begin{array}{c}0.06188 \\
(0.00819) \\
\end{array}$} & \multicolumn{2}{|c|}{$\begin{array}{c}0.06278 \\
(0.00995)\end{array}$} \\
\hline $\begin{array}{l}\text { Expected } \\
\text { Inflation }\end{array}$ & \multicolumn{2}{|c|}{$\begin{array}{c}1.105 \\
(0.112) \\
\end{array}$} & \multicolumn{2}{|c|}{$\begin{array}{c}1.106 \\
(0.1315) \\
\end{array}$} \\
\hline $\begin{array}{l}\text { Output } \\
\text { Gap }\end{array}$ & \multicolumn{2}{|c|}{$\begin{array}{l}0.01263 \\
(0.1858)\end{array}$} & \multicolumn{2}{|c|}{$\begin{array}{c}-0.3916 \\
(0.1965)\end{array}$} \\
\hline $\begin{array}{l}\text { Variable } \\
\text { Addition } \\
\text { Tests*** }\end{array}$ & $\begin{array}{l}\text { money growth } \\
\text { exchange rate }\end{array}$ & $\begin{array}{l}2.5909[0.0844] \\
1.8725[0.1457]\end{array}$ & & \\
\hline $\begin{array}{l}\text { Summary } \\
\text { Statistics }\end{array}$ & $\begin{array}{l}R^{2} \\
\sigma \\
D W \\
A R 1-4 F(4,51) \\
\text { ARCH } 4 \quad F(4,47) \\
\text { Normality } \chi^{2}(2) \\
\text { RESET } F(1,54)\end{array}$ & $\begin{array}{l}0.933781 \\
0.0143532 \\
1.93 \\
0.21108[0.9311] \\
5.3048[0.0013] \\
1.6867[0.4303] \\
1.6545[0.2038]\end{array}$ & $\begin{array}{l}R^{2} \\
\sigma \\
D W \\
A R \quad 1-4 F(4,46) \\
\text { ARCH 4 F } 4,42) \\
\text { Normality } \chi^{2}(2) \\
\text { RESET } F(1,49)\end{array}$ & $\begin{array}{l}0.9401850 .0138594 \\
1.76 \\
0.58269[0.6767] \\
2.0449[0.1054] \\
11.539[0.0031] \\
0.11753[0.7332]\end{array}$ \\
\hline
\end{tabular}

\section{Table 7. New Zealand}

*Derived from a RLS regression of the interest rate on a constant, one-quarter ahead expected inflation, output gap and one lag of the dependent variable.

**Derived from a RLS regression of the interest rate on a constant, two-quarter ahead expected inflation, output gap and one lag of the dependent variable.

***We tested for the addition of other regressors. Zero restrictions on lagged money growth, changes in the current and lagged trade-weighted index of effective exchange rate were tested by a F-version of the Wald test. P-values in brackets.

Asymptotic standard errors are in parentheses. AR is a LM test for the hypothesis of no serial correlation; ARCH checks whether residuals have an ARCH structure, with no ARCH as the null; Normality tests the normality of residuals; RESET tests the null of no functional misspecification. P-values in brackets 

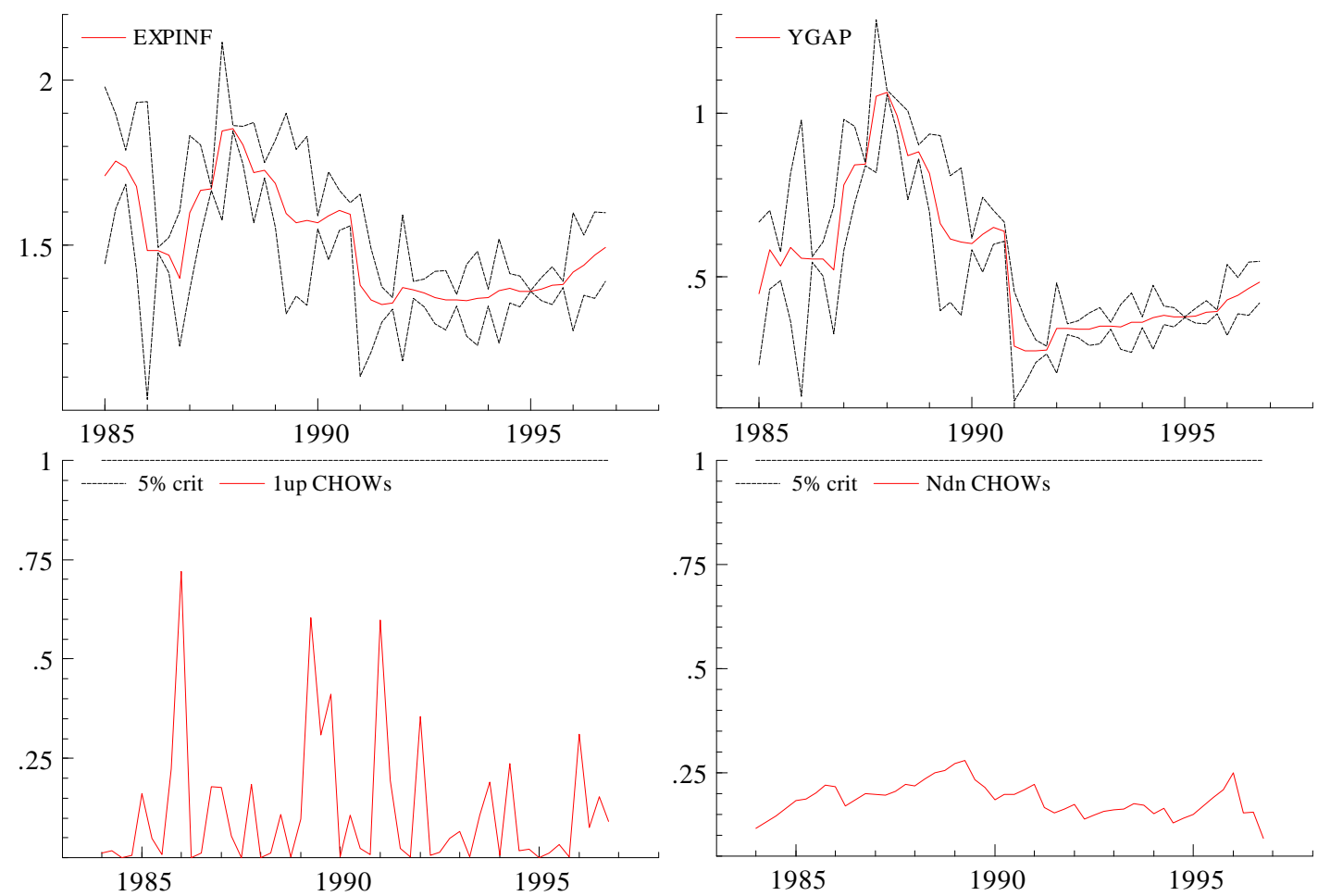

Figure 1. Germany. 1980(1)-1996(4). Recursive coefficients and standard error bands; 1-step, N-step up Chow tests $(5 \%)$
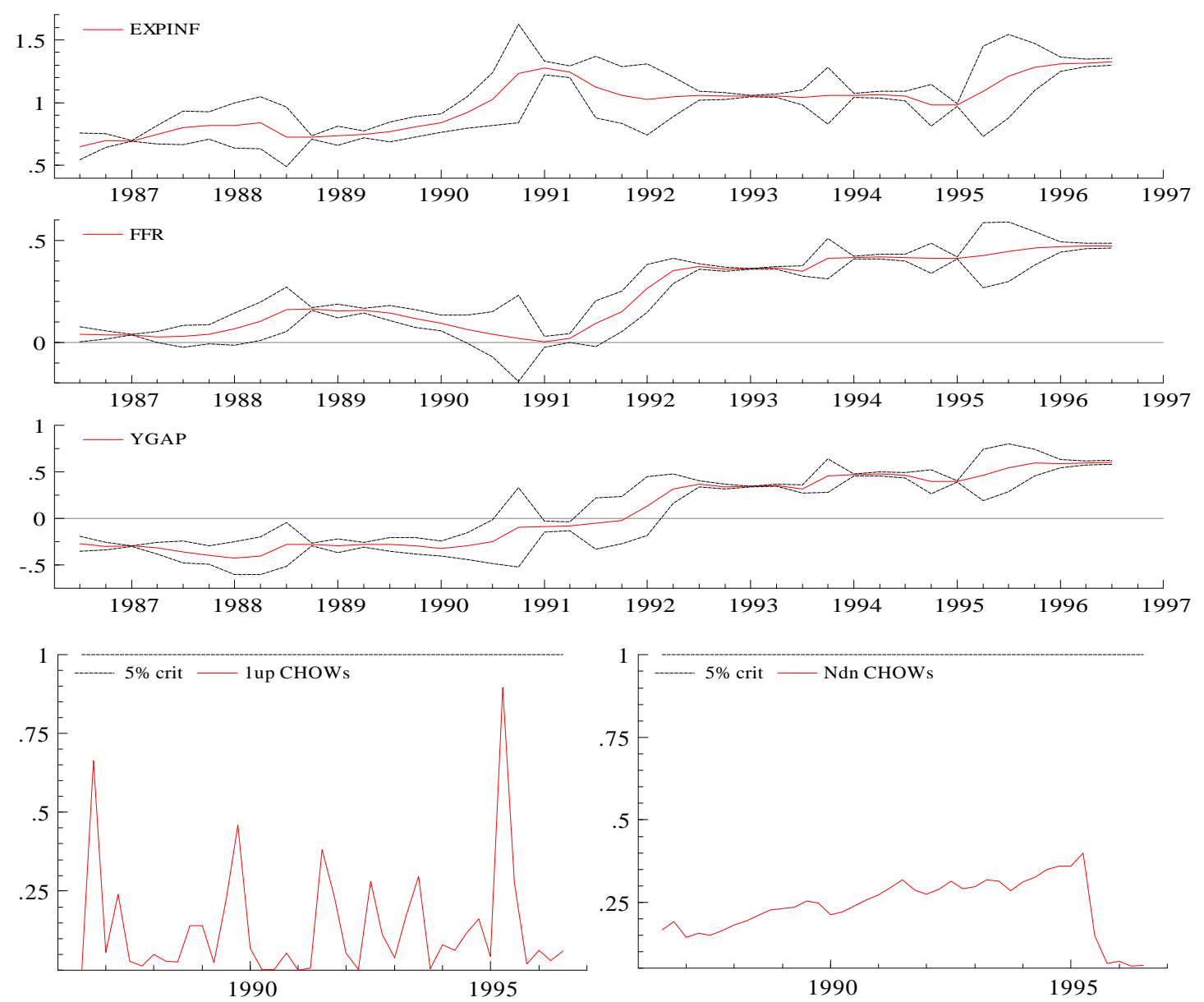

Figure 2. Japan. 1982(1)-1996(3). Recursive coefficients and standard error bands; 1-step, N-step up Chow tests $(5 \%)$ 

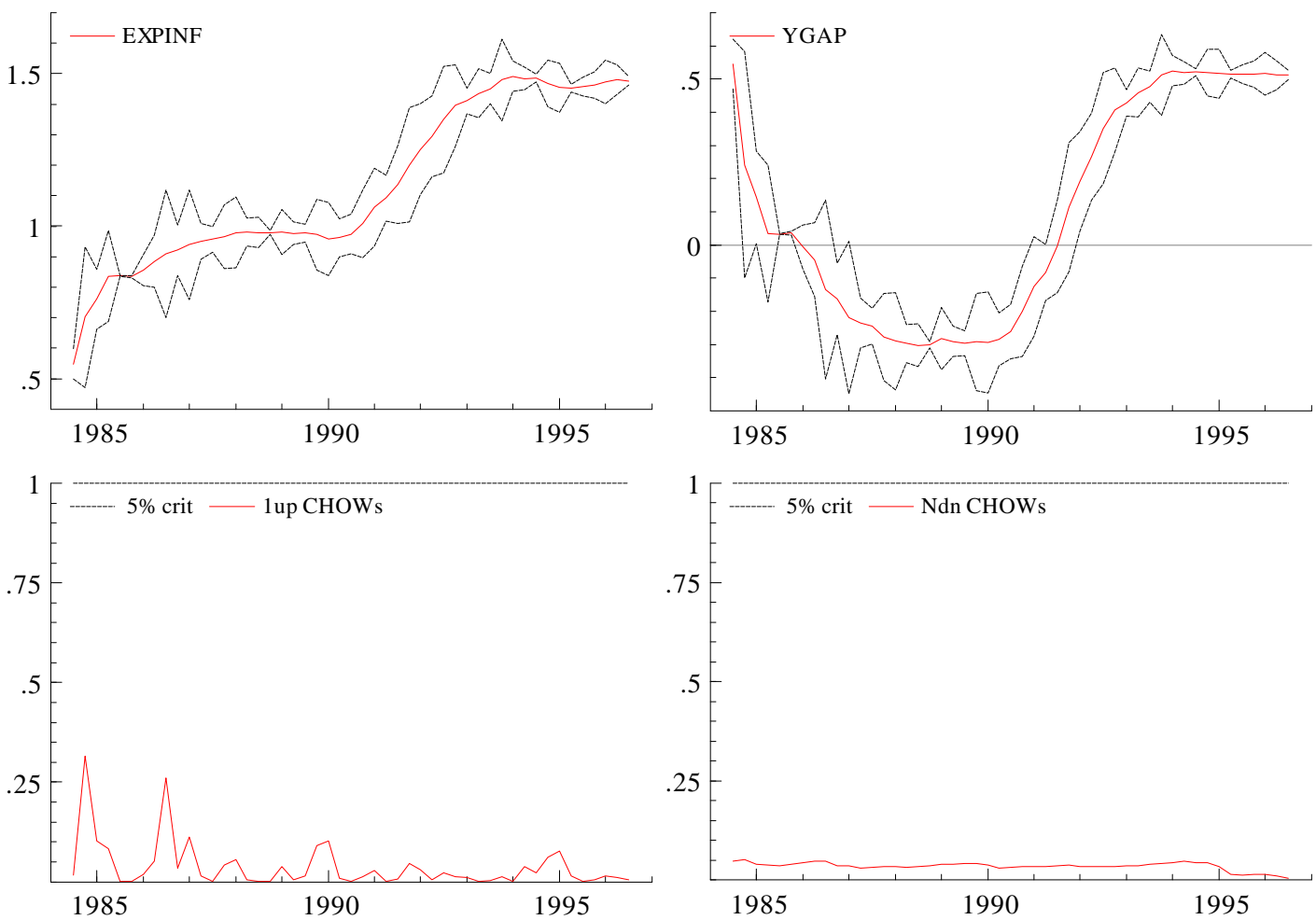

Figure 3. USA. 1980(1)-1996(3). Recursive coefficients and standard error bands; 1-step, $\mathrm{N}$-step up Chow tests $(5 \%)$ 

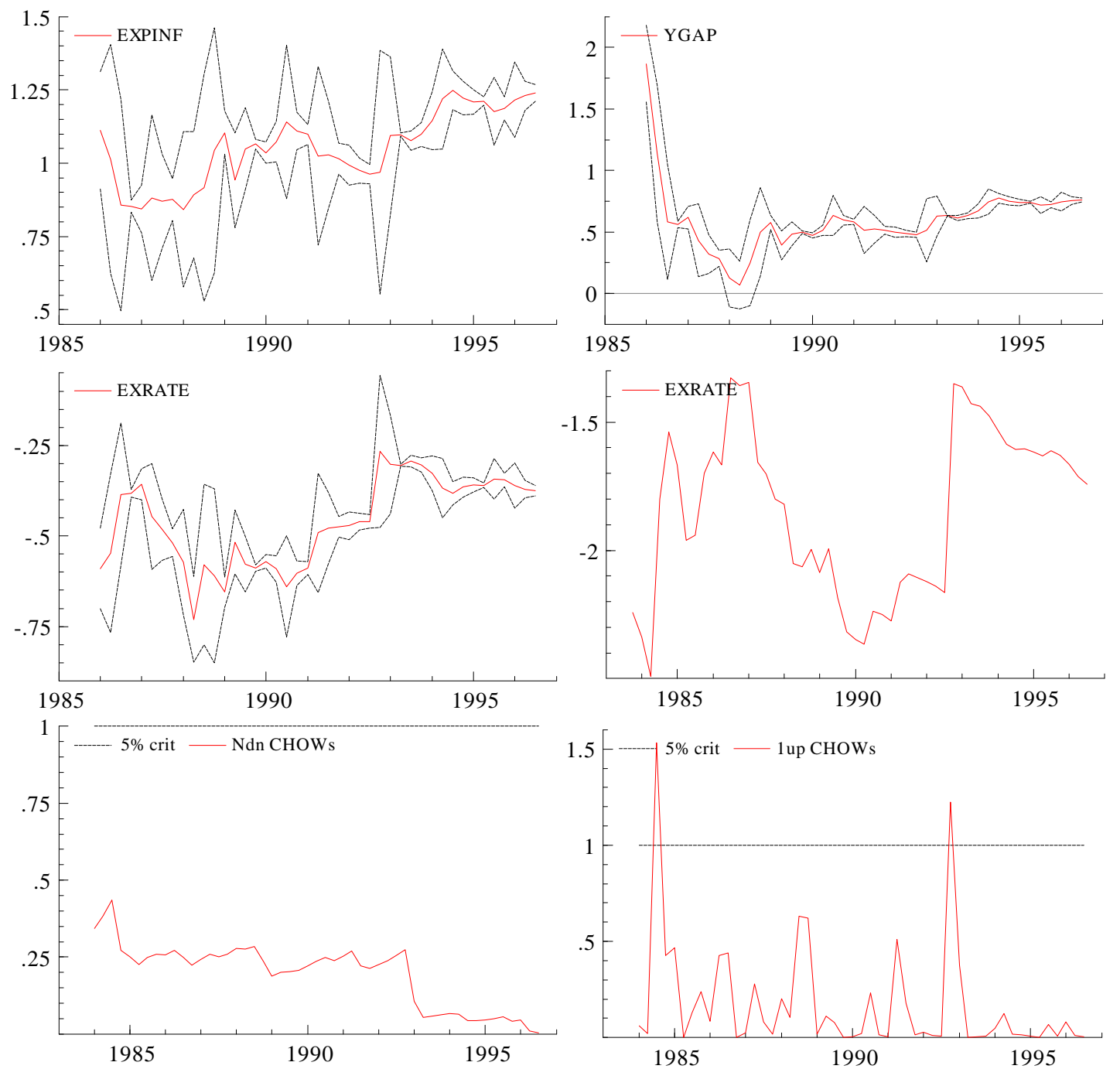

Figure 4. United Kingdom. 1980(1)-1996(3). Recursive coefficients and standard error bands; t-ratio for the exchange rate coefficient; 1 -step, N-step up Chow tests $(5 \%)$ 

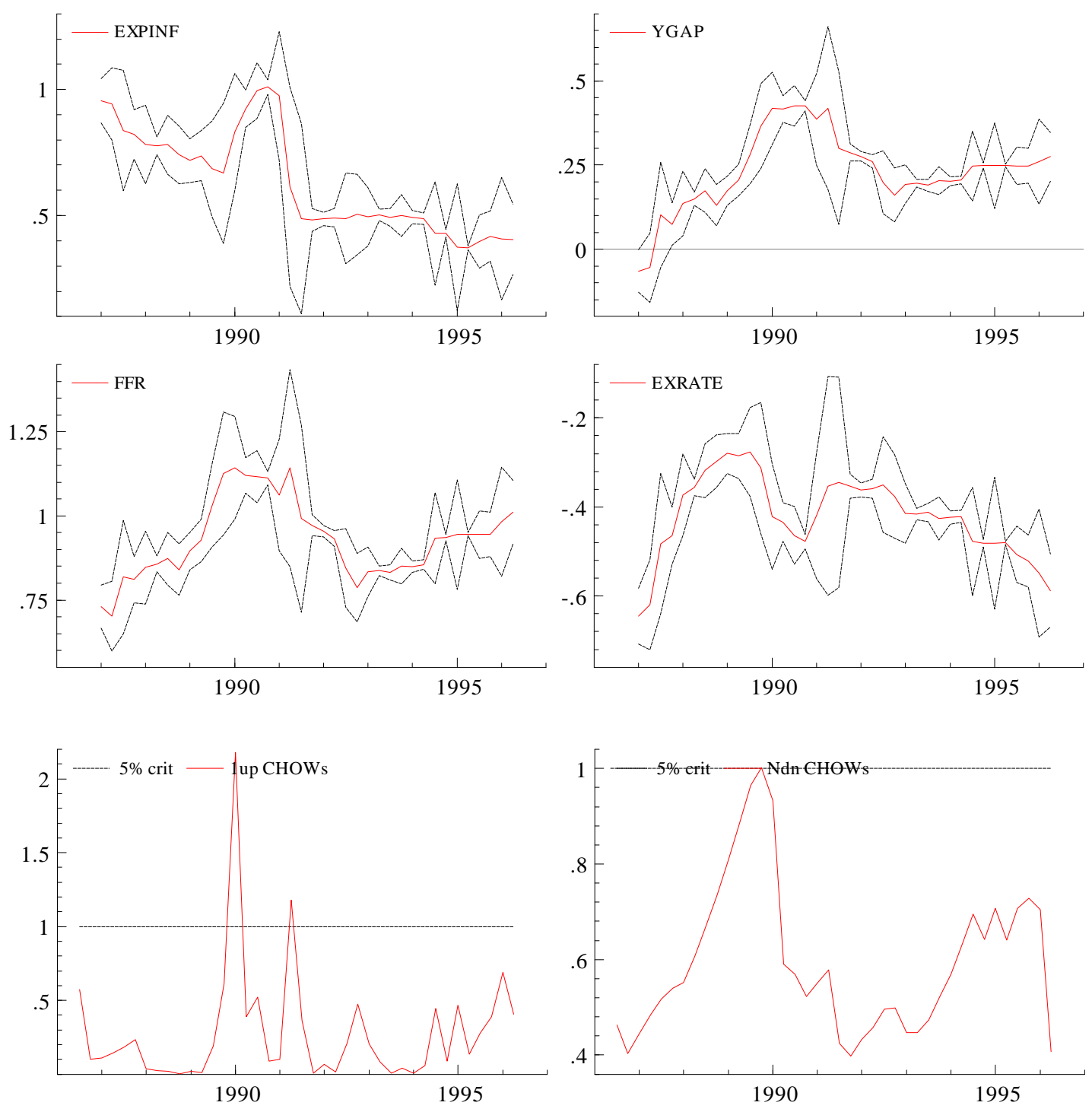

Figure 5. Canada. 1982(2)-1996(2). Recursive coefficients and standard error bands; 1-step, N-step up Chow tests $(5 \%)$ 

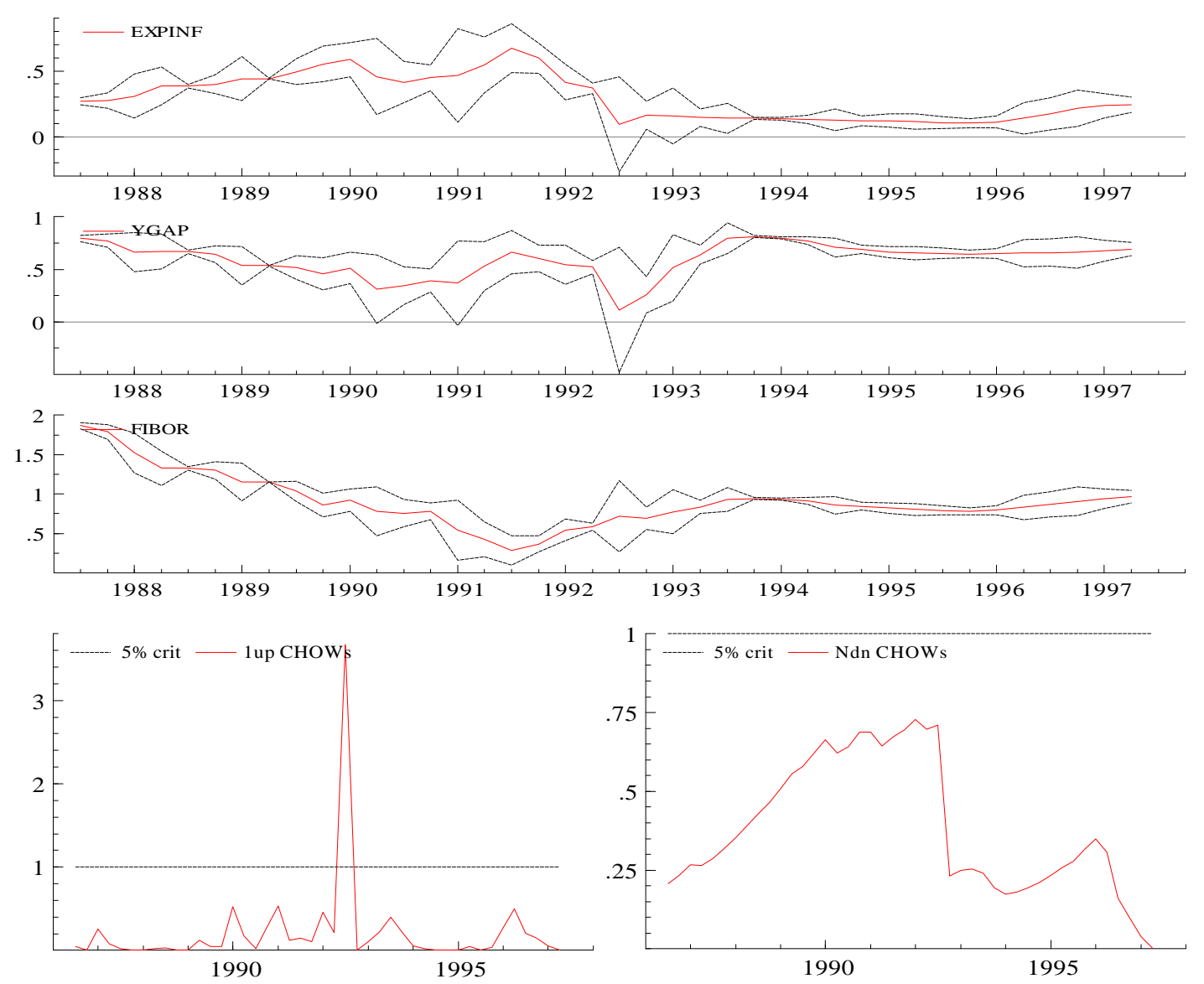

Figure 6. Sweden. 1982(2)-1997(2). Recursive coefficients and standard error bands; 1-step, N-step up Chow tests $(5 \%)$
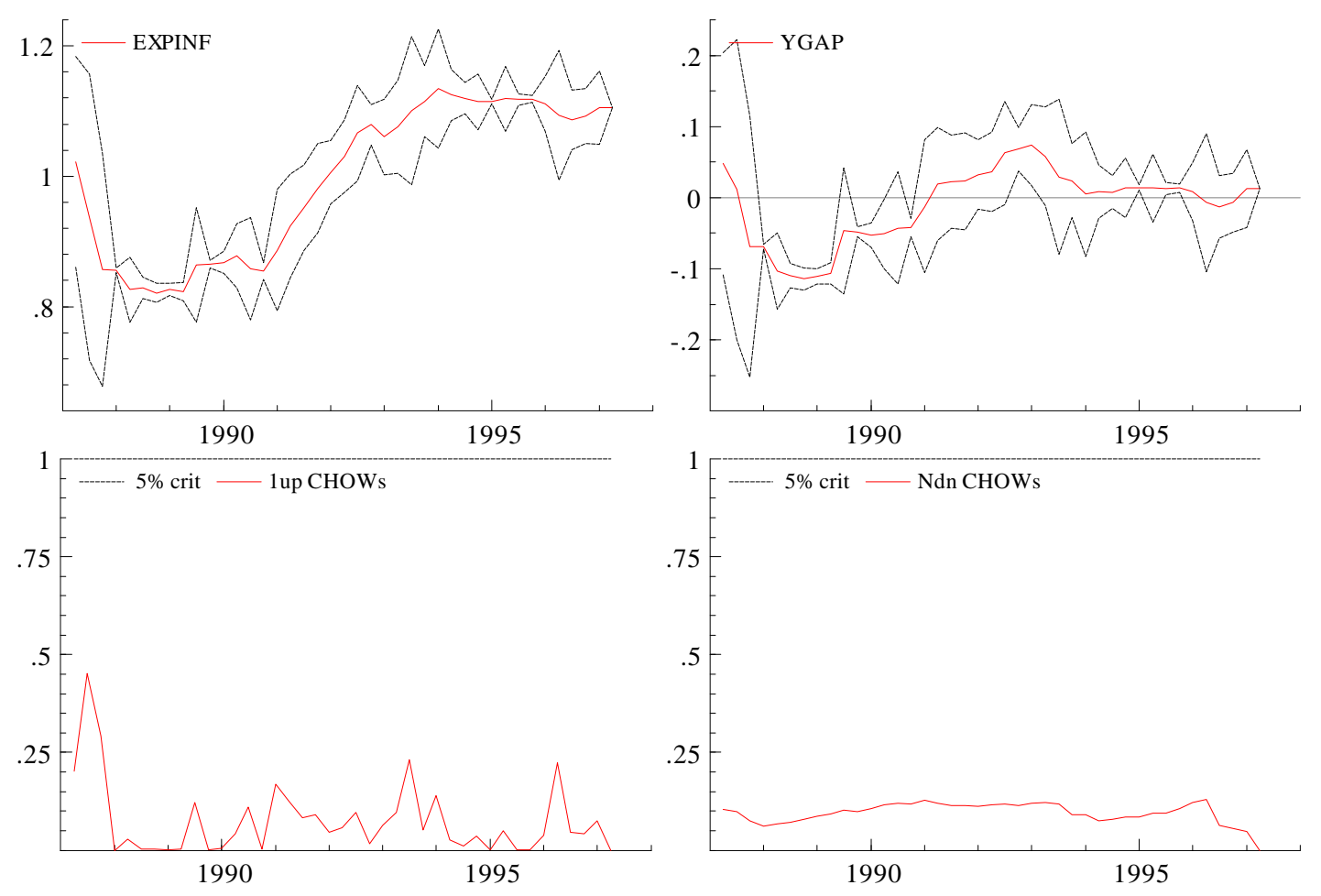
Figure 7. New Zealand. 1982(4)-1997(2). Recursive coefficients and standard error bands; 1-step, N-step up Chow tests $(5 \%)$ 


\section{Data Appendix}

The data we used were quarterly series, extracted from OECD Main Economic Indicators, apart from a few cases, in which the source is equivalently quoted. In most cases we were able to employ seasonally adjusted data.

For each country we measured output using the GDP at constant prices series. For Sweden and New Zealand the available constant price series for GDP do not date back further than 1980 and 1982Q2, respectively. The inflation series were defined as simple 4-quarter log-differences in the all-items CPI, except for Britain, where it was the equivalent change in the index of retail prices excluding mortgage interest payments (not available before 1975).

The index of effective exchange rates (trade weighted) was the measure for the exchange rates. Also, spot exchange rates vis-a-vis the US dollar were tried for Japan, Germany, Canada, New Zealand and the UK; vis-a-vis the German mark for the UK and Sweden.

The rate on US Federal Funds was used as the foreign interest rate for Japan, Germany, Canada and New Zealand. The 3-month FIBOR German rate was the foreign rate for the UK and Sweden.

Below we briefly outline the short-term interest rates we chose as policy indicators, along with the monetary aggregates we applied in the generation of regressors. The rates are generally converted from monthly series. 
USA

JAPAN

GERMANY

$U K$

CANADA

SWEDEN

$N E W$

ZEALAND
Federal Funds Rate. As noted in the main text, during the early to mid-80s the FFR provides an accurate measure of the Fed's policy stance. The only exception is the Volcker experiment in the 1979-82 period, when the Fed's operating procedures could be better summarised by a different instrument choice (inter alia, Bernanke and Mihov, 1995; Goodfriend, 1995)

The Call Money Rate (rate between financial institutions, source Bank of Japan) is directly affected by the Bank of Japan reserve management policy, through discount window and open market operations (see Ichimura, 1993)

M2 plus

CD

The Bundesbank's intentions are mainly reflected by the rate in the market for interbank reserves, the Call Money Rate. In facts, the discount window lending to commercial banks exclusively affected the behaviour of this rate until 1985, when the banks started to be supplied with reserves by repurchase operations. Since then the call rate shadows the rate on these loans (REPO rate). (see Bernanke and Mihov, 1997; Clarida and Gertler, 1997)

We use an Overnight Interbank Rate series post-1983. This is not available pre-1983, and we use the Rate on 90-day Treasury Bills, which displays a very close correlation with the interbank lending rate, for those observations (source: IMF, IFS).

The Bank of Canada introduced in 1996 the concept of Monetary Conditions Index (MCI) as its short-run operational target. The changes in the index are defined as a weighted average of the changes in the 90-day commercial paper rate and the changes in a tradeweighted Can\$ exchange rate. Although the MCI was computed backward and onward from 1987, the Overnight Money Market Rate (available from 1975) is clearly a superior indicator of the Bank's policy stance

During the fixed exchange rate regime the overnight rate in the interbank market represented the Riksbank's favourite instrument to keep the desired krona's parity. Then, after the switch to the inflation targeting regime, the Repo rate has become the Bank's operational instrument. The sake of homogeneity and continuity suggested to use the Rate on 3-month Treasury Discount Notes (not available before 1982), which roughly shadows the behaviour of both marginal and Repo rates (Baumgartner et al., 1997).

The Rate on 90-day Bank Bills (not available before 1974) was our choice. Until March 1985 New Zealand has pursued a policy of adjustable pegged exchange rate. "...the instrument since 1985 has been the quantity target for settlement balances held at the Reserve Bank. Settlement cash is used by commercial banks for end-of-day settlements with each other and the government. Should the banks run out of cash during the settlement period, further cash is available from the Reserve Bank by discounting Reserve Bank bills of short maturity at a penalty rate of $1.5 \%$ above market rates...Such an approach allows interest rates to move quickly, particularly when the change involves a politically unpopular increase in interest rates..." (Fischer, 1995, page35) It is then understandable why banks prefer to act in the bank bills market, whose short-term interest rate tends to react rapidly to changes in policy intentions.
M1, M2plus**

\footnotetext{
*The Bundesbank announced targets for the growth of Central Bank Money until 1987, when it switched to M3, which we chose. The two move very closely together, apart from two episodes of divergence in 1988 and 1990-91. Notwithstanding the official target is announced in terms of base-money growth, the evidence points to Germany as to an "atypical" inflation targeter, who influences the money markets through changes in a day-to-day rate (Neumann and von Hagen, 1993; von Hagen, 1995; Bernanke and Mihov, 1997; Mishkin and Posen, 1997).

** Until 1982 the Bank of Canada was committed to target M1. It is now following closely also the behaviour of M2+ to get some clues about future inflation (Freedman, 1995).
} 
Appendix A: Estimates of Output Gaps and Expected Inflation
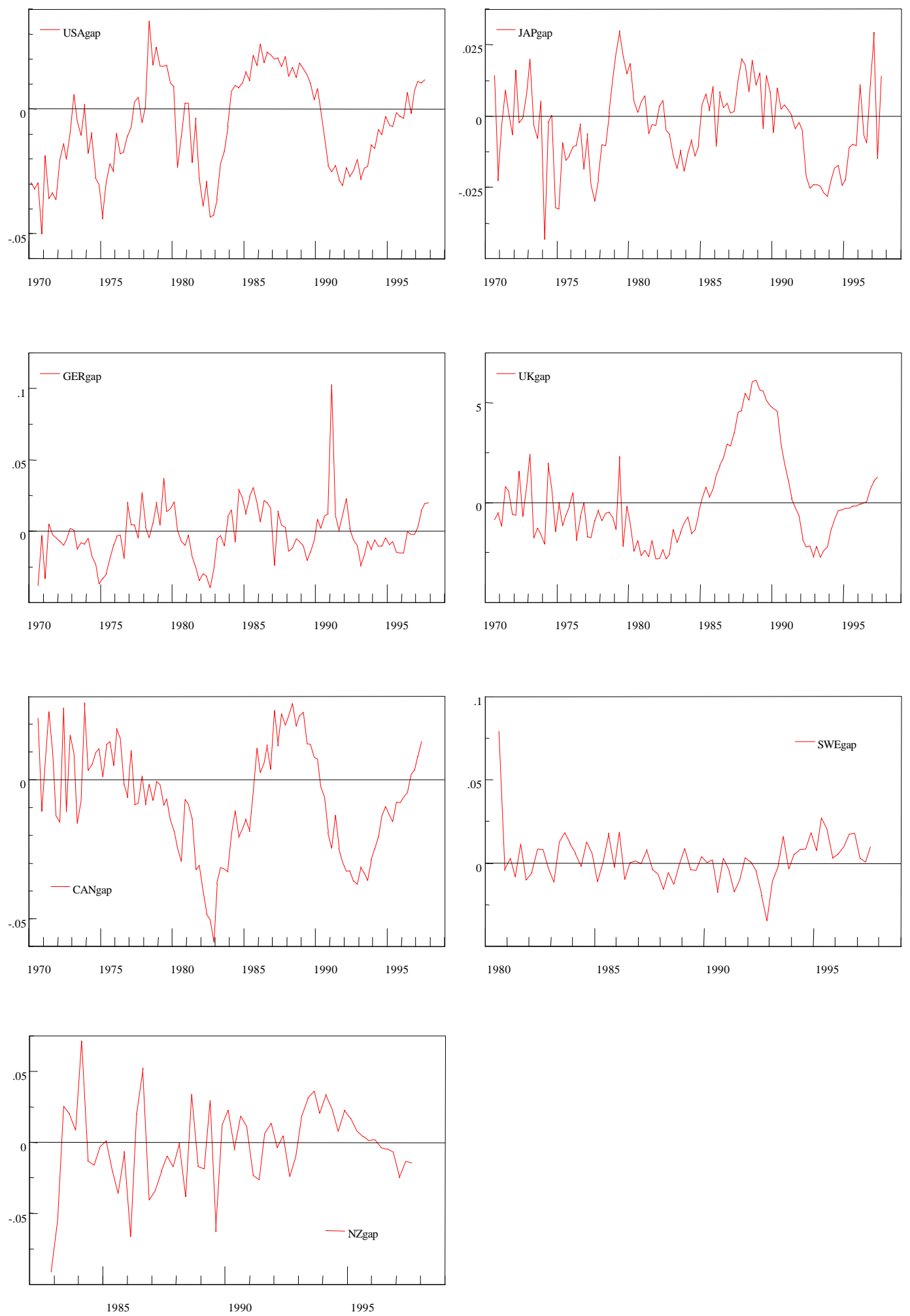

Figure A.1 - Output gaps 

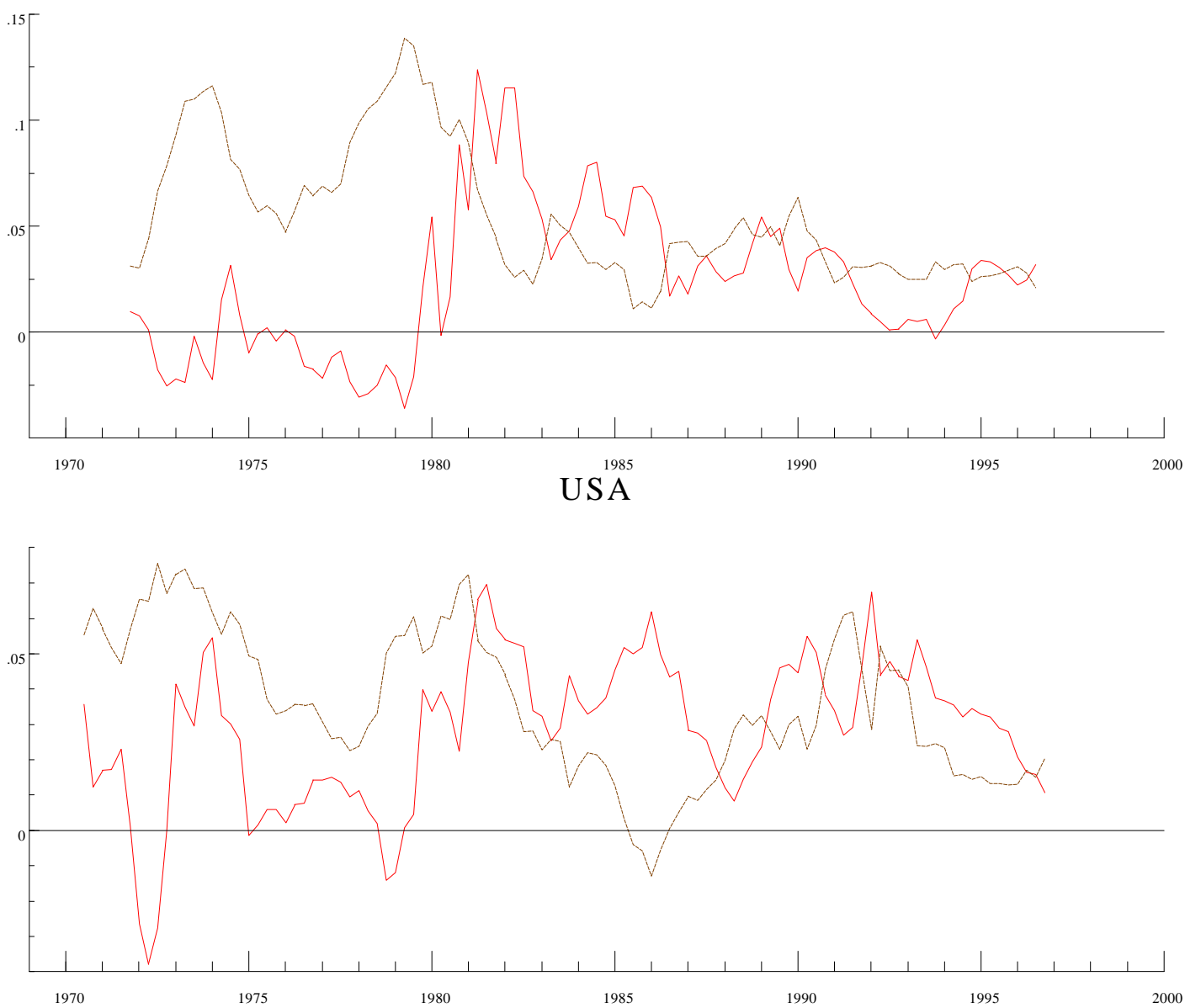

Germany

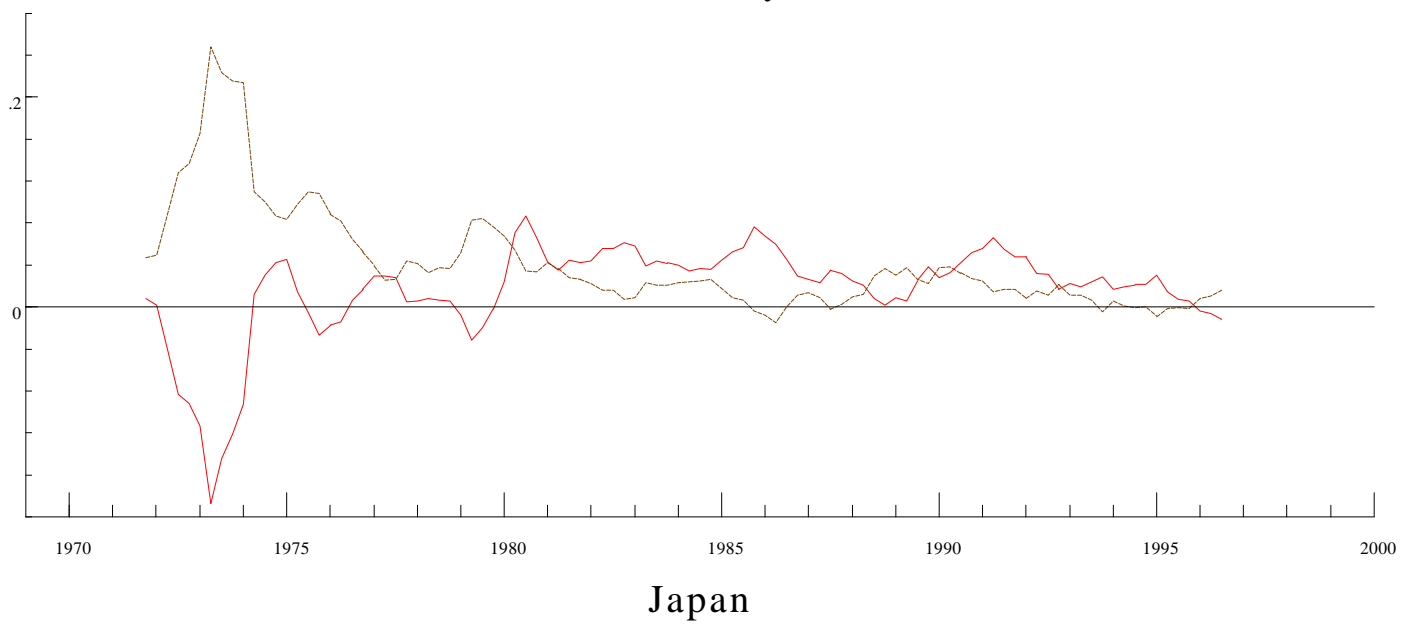

Figure A.2 - USA, Germany, Japan : Ex ante real interest rates (solid lines) and (4-quarter ahead) expected inflation (dotted lines) 
United Kingdom
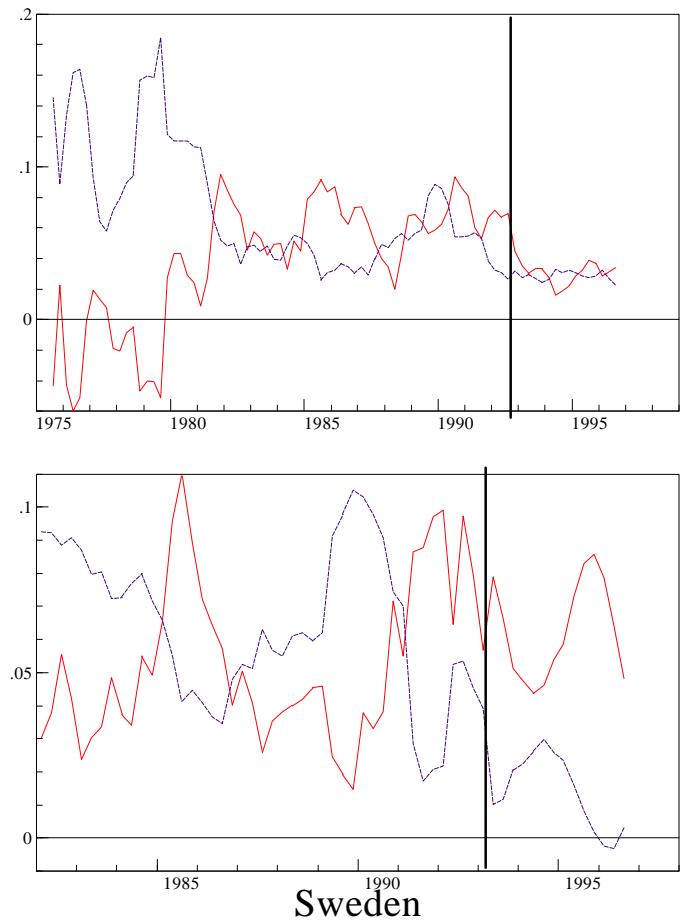

Canada
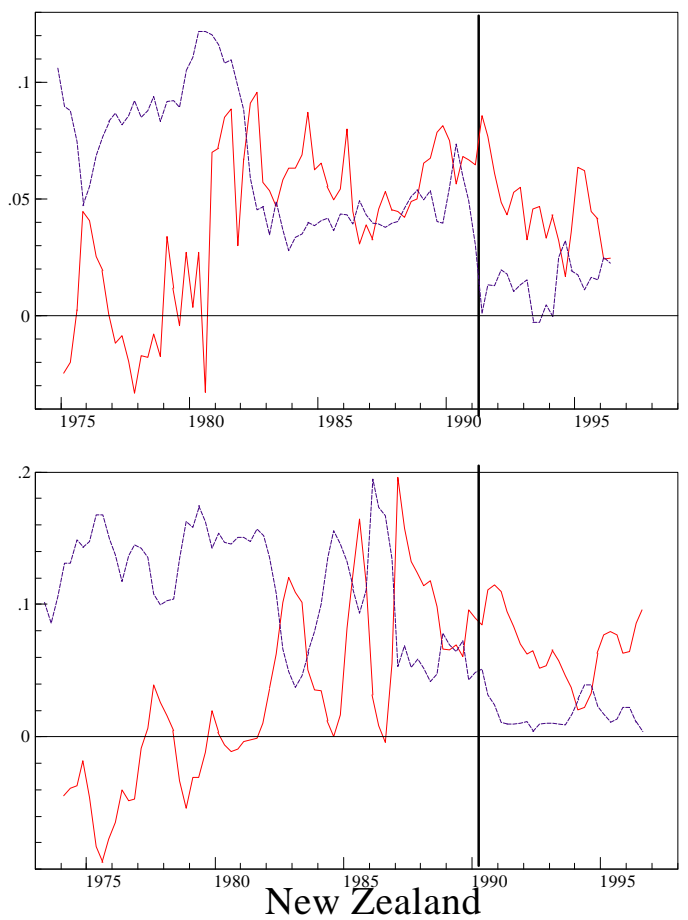

Figure A.3 - United Kingdom, Canada, Sweden, New Zealand Ex ante real interest rates (solid lines) and (4-quarter ahead) expected inflation (dotted lines). The vertical lines represent the announcement of inflation targets 